
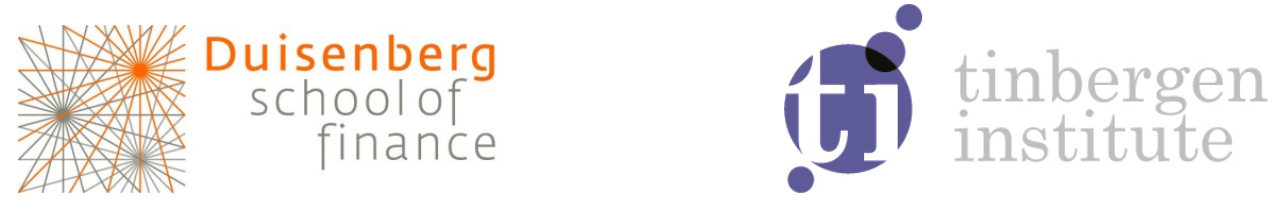

Duisenberg school of finance - Tinbergen Institute Discussion Paper

TI 13-032/IV/DSF 52

Proprietary Trading and the Real Economy

Stefan Arping

Faculty of Economics and Business, University of Amsterdam, and Tinbergen Institute. 
Tinbergen Institute is the graduate school and research institute in economics of Erasmus University Rotterdam, the University of Amsterdam and VU University Amsterdam.

More TI discussion papers can be downloaded at http://www.tinbergen.nl

Tinbergen Institute has two locations:

Tinbergen Institute Amsterdam

Gustav Mahlerplein 117

1082 MS Amsterdam

The Netherlands

Tel.: +31(0)205251600

Tinbergen Institute Rotterdam

Burg. Oudlaan 50

3062 PA Rotterdam

The Netherlands

Tel.: +31(0)10 4088900

Fax: $+31(0) 104089031$

Duisenberg school of finance is a collaboration of the Dutch financial sector and universities, with the ambition to support innovative research and offer top quality academic education in core areas of finance.

DSF research papers can be downloaded at: http://www.dsf.nl/

Duisenberg school of finance

Gustav Mahlerplein 117

1082 MS Amsterdam

The Netherlands

Tel.: +31(0)205258579 


\title{
Proprietary Trading and the Real Economy
}

\author{
Stefan Arping*
}

February 14, 2013

\begin{abstract}
We embed proprietary trading into a model of bank lending. Opportunities to engage in purely speculative trading can harm the real economy. This is because banks, when devoting cheap but scarce deposits to lending rather than to gambling, must be compensated for giving up gambling rents. This makes corporate loans more costly, stifling real economic activity. Worse, gambling can crowd out lending, forcing firms to seek costly bond financing. By contrast, when trading is required for the provision of complementary banking services, banks may actually engage in too little trading. Ring-fencing trading can facilitate the efficient provision of banking services.

Keywords: Proprietary Trading; Volcker Rule; Disintermediation; Shadow Banking; Depositor Preference; Safe Harbors; Covered Bonds; Ring-fencing; Financial Stability JEL Classification: G2, G3
\end{abstract}

${ }^{*}$ University of Amsterdam, Faculty of Economics and Business, Finance Group, Roetersstraat 11, 1018 WB Amsterdam, The Netherlands, e-mail: s.r.arping@uva.nl, and Tinbergen Institute 


\section{Introduction}

This paper presents a model where banks, in addition to "traditional" lending and deposit taking, can engage in proprietary trading. By proprietary trading, we mean any type of activity where banks engage in the trading of securities, currencies, and so forth on own account - that is, risking own as opposed to client funds. ${ }^{1}$ This can involve purely "speculative" trading unrelated to client or hedging needs - often referred to as "pure" proprietary trading - but it also pertains to trading activities related to market making and the provision of complementary banking services, such as corporate treasury services. ${ }^{2}$ We use this framework to address a number of fundamental questions. What is the impact of trading opportunities and banks' engagement in trading on the real economy? Can trading complement lending? Or might it crowd out lending? Is there a tradeoff between efficiency and financial stability? Would banks engage in too much trading? Or too little? If so what is the role of regulation?

These questions are central to ongoing policy debates and initiatives concerning safety net protected banks' engagement in trading. ${ }^{3}$ In the United States, deposit taking banks have recently been prohibited from engaging in "pure" proprietary trading ("Volcker Rule"). In Europe, discussions are underway to "ring-fence" banks' traditional lending and deposit taking businesses, limiting the safety net to these activities and insulating them from,

\footnotetext{
${ }^{1}$ This excludes activities where banks trade on behalf of clients, execute client orders, or merely match buyers and sellers, i.e., act as an intermediary without risking own funds. There is, of course, much debate on what types of activities "proprietary trading" does or does not entail. In this paper, we take the view that any type of trading where banks risk own funds should be deemed "proprietary".

${ }^{2}$ See Duffie (2012a) for an excellent discussion of the social benefits of market making.

${ }^{3}$ See Duffie (2012b) for an insightful discussion of post-crisis policy initiatives concerning the boundaries of the banking system. Of course, the debate on what types of activities regulated banks should and should not engage in is a long-standing one. See Drucker and Puri (2007) for a survey of the literature on combining lending and underwriting and, more generally, commercial banks' role in capital markets.
} 
among other things, trading exposures (Vickers et al. 2011; Liikanen et al. 2012). ${ }^{4}$ Meanwhile, governance and risk management failures at banks continue to fuel the wider public's perception that banking is, by and large, akin to casino gambling.

In our model, a bank can extend loans to entrepreneurs who require external funding for their projects. Entrepreneurs can improve the likelihood of project success by exerting unobservable and privately costly effort. The bank funds its activities with retail deposits and, potentially, wholesale funding. Whereas retail deposits are insured by a governmentfunded deposit insurance agency, ${ }^{5}$ all other securities are uninsured. Thus, retail deposits, being subsidized by the safety net, constitute a relatively "cheap" source of funding. The bank operates in a competitive credit market, forcing it to pass on safety-net subsidies to entrepreneurs in the form of lower loan rates. This has positive implications for entrepreneurs' incentive to exert effort. Thus, by easing credit constraints and supporting real economic activity, safety-net subsidies can be useful in our economy.

In addition to lending, the bank can engage in trading. We consider arbitrage-free financial markets where trading in itself constitutes a zero NPV activity. In this setup, one reason why trading can be beneficial for society is that it addresses client needs. ${ }^{6}$ Yet, while some forms of trading are socially beneficial, others, such as purely "speculative"

\footnotetext{
${ }^{4}$ We use the term "ring-fencing" in the sense of the Vickers proposal: insulating a set of banking activities and the investors backing these activities from exposures elsewhere in the banking group. The Vickers proposal involves ring-fencing retail banking and insulating it from wholesale exposures. The Liikanen proposal involves isolating, among other things, trading and ring-fencing all other activities.

${ }^{5}$ The empirical relevance of this assumption stems from the observation that deposit insurance underpricing seems to be the rule rather than the exception (Demirgüc-Kunt et al. 2005). Implicit guarantees, which are often argued to be even greater in magnitude than explicit deposit insurance, tend to be underpriced, too (Noss and Sowerbutts 2012). At any rate, the thrust of our argument does not rely on the presence of safety-net subsidies, as will be discussed in Section 5 .

${ }^{6}$ Quoting foreign exchange rates and standing ready to trade currencies at these rates is, perhaps, the simplest example of an activity where banks engage in socially useful trading.
} 
trading, may be less likely to create value for society. ${ }^{7}$ However, they may still create value for the bank: as there is no default premium attached to insured deposits, devoting them to zero NPV gambles allows the bank to extract safety-net subsidies and make a profit. The main question we ask is how opportunities to engage in trading - "socially useful" on the one hand and "socially useless" on the other-affect the real economy.

Our first observation is that opportunities to engage in socially useless speculative trading ("gambling") can be detrimental to welfare. This is not because gambling is inefficient per se, but because the presence of gambling opportunities entails a negative externality on the real economy. The argument runs as follows. Insured deposits are scarce in our model, and, as a result, the bank has to choose between devoting deposits to gambling or to lending. While the bank could raise additional funds from the wholesale market and engage in both gambling and lending, ${ }^{8}$ doing so would be unprofitable relative to lending only. This is because, due to depositor preference, the returns from gambling would, in first instance, be used to satisfy depositors' claims. ${ }^{9}$ Thus, gambling in addition to lending makes it harder for the bank to extract subsidies from the safety net, and it will, therefore, engage either in gambling or in lending but not both. The implication is that entrepreneurs

\footnotetext{
${ }^{7}$ However, even purely "speculative" trading can be beneficial to society. This is because it can make financial markets more liquid, facilitating risk sharing and diversification. The key issue here is whether such activities need to be performed by commercial banks. We will come back to this in Section 7 .

${ }^{8}$ Notice that it is not funds that are scarce in our model, but cheap funds.

${ }^{9}$ In the majority of G20 countries, including the United States, depositors have, by law, preference in the event of bank failure (e.g., Clifford Chance 2011). Yet, even in those countries, depositor preference is not universal. For instance, counterparties in derivative transactions and repurchase agreements are often granted exemption from automatic stay ("safe harbors"). Such counterparties can then settle their claims before everybody else does, putting them ahead of the queue. Covered bond financing is another example of how non-depositors can effectively be given seniority. Covered bonds are secured by dedicated pools of assets. They have a long history in some European countries and have been recently introduced in the United States. Throughout our main analysis, we assume universal depositor preference, but we will also look into the desirability of implicit or explicit departures from depositor preference.
} 
will have to compensate the bank for its lost gambling rents when it devotes deposits to lending. Corporate loan rates rise, stifling entrepreneurs' incentive to exert effort. Worse, gambling may crowd out lending. When gambling is highly lucrative for the bank, bank loans simply become too expensive for entrepreneurs and they seek costly bond financing. ${ }^{10}$ Thus, gambling opportunities can spur disintermediation: banks reduce their lending activities and focus on gambling, and entrepreneurs tap the bond market. Furthermore, regardless of whether banks ultimately engage in gambling, the mere possibility of doing so will make banks riskier, jeopardizing financial stability.

The next step in our analysis is to introduce value-enhancing trading. Specifically, we consider a setting where lending and provision of corporate treasury services, such as foreign exchange hedging and transaction services, are complementary. Due to their informational advantage from lending, banks may have a unique advantage in providing such services to their borrowers. Yet doing so requires taking risks and engaging in trading. In our model, the effect of treasury services is that they create additional returns in project failure states, thus making debt less risky. This induces the bank to reduce the loan rate, which, in turn, has positive implications for incentives. However, in sharp contrast to the case of purely speculative trading, now the bank may engage in too little trading. One reason for this is that depositor preference can give rise to a debt overhang problem, making it unprofitable for banks to invest in trading. ${ }^{11}$ As we shall see, safe harbors, covered bond financing, or ring-fencing trading can address this problem and, in doing so, facilitate the efficient provision of banking services. Another reason why the bank may not engage in socially useful trading is that it may be crowded out by socially useless trading. The threat of gambling still makes loans more expensive and potentially too expensive. As the provision of treasury services is tied to lending, gambling may crowd out not only lending, but also

\footnotetext{
${ }^{10}$ Bond financing is inherently costly in our model due to bond issuance transaction costs.

${ }^{11}$ For precisely the same reason, the bank will not engage in lending and gambling in our base model.
} 
trading activities that are related to the provision of treasury services.

Our analysis has several policy implications. Fair deposit insurance pricing, which, in our model, is suboptimal in the absence of trading opportunities, can be optimal in the presence of trading opportunities. This is because it reduces safety-net subsidies to banks, making gambling less lucrative. Capital requirements have a similar effect. Regulators may also want to restrict the scope of trading along the lines of the Volcker Rule in the United States, but doing so runs the risk of putting in place too tight or ambiguous restrictions (cf., Duffie 2012a; Thakor 2012). This may undermine banks' ability to engage in socially useful trading or may reduce their incentive to do so. In particular, to the extent that trading is required for the provision of banking services that complement lending, banks may be less able or less inclined to provide such services to corporate borrowers. ${ }^{12}$

Recent policy proposals suggest the possibility of ring-fencing banks' core banking businesses (Vickers et al. 2011; Liikanen et al. 2012). The idea is to insulate core banking activities from exposures elsewhere in the banking group and limit the safety net to such activities. In the context of our model, this would have the advantage of making speculative trading in securities markets less lucrative for banks, which, in turn, would have positive implications for real economic activity. Yet our analysis will also show that ringfencing can backfire. Precisely by making gambling in securities markets less lucrative, ring-fencing lending may spur even more destructive gambling in lending markets.

The model also generates a number of empirical predictions. For example, to the extent that financial market deepening facilitates riskier trading, the model would predict a non-monotonic relationship between financial market development and economic growth, attaining an optimum at some level, after which further development would be counter-

\footnotetext{
${ }^{12}$ Yet our analysis also shows that limiting banks' ability to engage in socially useless trading can help to "crowd in" socially useful trading. The key issue here is whether it is practically feasible to distinguish between "socially useful" and "socially useless" trading.
} 
productive (for empirical evidence, see Cecchetti and Kharroubi 2012). ${ }^{13}$ The model's empirical predictions will be discussed in more detail in Section 6 .

This paper is related to several strands of the literature. There is a large literature looking into the merits of banks engaging in transferring and trading credit risks, and analyzing the impact of credit risk transfer on credit market efficiency, credit availability, and financial stability. ${ }^{14}$ While this literature is highly relevant to the question of how the deepening of financial markets - and, thus, the ease by which banks can lay off credit risks - may affect the real economy, it is somewhat orthogonal to our paper, as we focus on the real effects of banks' engagement in securities trading and market making.

Our paper is more closely related to the literature on scope economies in banking. Central to this literature is the notion that combining activities such as lending and securities underwriting can give rise to scope benefits, but that it may also entail conflicts of interest or make banks "too risky" (for a survey, see Drucker and Puri 2007). In recent work, Loranth and Morrison (2012) present a model where banks can provide complementary services to borrowers. The additional surplus generated by these services can have positive implications for borrower incentives ex ante, but it may also undermine banks' commitment to cut refinancing following poor performance, which would have the opposite incentive effect. Depending on which of these effects dominates, integration of non-lending activities is optimal or suboptimal in their model. Closest in spirit to our paper is Boot and Ratnovski (2012), who also look into the merits of combining lending with trading. In their model, trading is not feasible as a stand-alone business due to credit constraints. However, when combined with relationship lending, setting up a trading business can be lucrative, as banks

\footnotetext{
${ }^{13}$ This is because, on the one hand, financial market development enables banks to engage in riskier and, hence, more lucrative speculative trading, which is harmful to the real economy. On the other hand, however, it also facilitates socially useful trading that complements lending and supports the real economy. ${ }^{14}$ For recent work, see, e.g., Allen and Carletti (2006), Wagner (2007), Parlour and Plantin (2008), Bolton and Oehmke (2011), Campello and Matta (2012), Parlour and Winton (2013), and Arping (2013).
} 
can deploy excess capital from non-scalable, profitable lending to expand into trading. Yet banks may be tempted to allocate too much capital to trading, thus compromising lending relationships, and they may use trading for inefficient risk-shifting.

Another related literature looks into the concern that the financial sector may absorb too many resources - talent, in particular - from the rest of the economy (see Murphy et al. 1991; Phillipon 2008; Wuergler 2009; Bolton et al. 2011; Cahuc and Challe 2012; and, on the empirical front, Phillipon 2008; Phillipon and Reshef 2012; and Kneer 2012). For example, Bolton, Santos, and Scheinkman (2011) have a model where agents can choose to become entrepreneurs or dealers in over-the-counter financial markets. Dealers provide incentives for entrepreneurs to originate high quality assets, but the opacity of the OTC market enables dealers to cherry pick assets and extract excessively high rents, making "finance" too attractive an occupational choice. A key difference between the occupational choice literature and our paper is that we are not concerned with the allocation of resources between sectors. Rather, the point we wish to make is that opportunities to engage in socially less useful activities in finance (gambling) can crowd out the provision of useful financial services (lending and banking services) or make them more expensive. ${ }^{15}$

The paper is organized as follows. Section 2 develops a model of corporate lending in the absence of trading opportunities. Section 3 considers the case of purely speculative trading. Section 4 allows for scope economies between lending and trading. Extensions are discussed in Section 5. Section 6 provides a discussion of the model's empirical implications. Section 7 concludes. Proofs are relegated to the Appendix.

\footnotetext{
${ }^{15}$ See Glode, Green, and Lowery (2012) for a model where dealers can invest in (socially useless) financial expertise. Expertise improves dealers' ability to estimate value when trading a security, which deters opportunistic bargaining by counterparties, but in equilibrium this advantage is neutralized by offsetting investments by competitors. Ultimately, investments in expertise are socially harmful, as the adverse selection created by expertise can trigger liquidity breakdowns in times of heightened volatility.
} 


\section{Basic Model and Analysis}

We start with a simple model of corporate lending in an economy where banks cannot engage in trading. Trading opportunities will be introduced in Section 3.

At the center of the model is a representative bank with no capital and no assets in place. The bank finances its activities with retail deposits and, potentially, "wholesale" funding (e.g., wholesale deposits, bonds, equity). Retail deposits are insured by a governmentfunded deposit insurance agency. ${ }^{16}$ All other securities are uninsured. For the moment, we assume that insured deposits are senior to all other securities. In other words, insured depositors have, without exception, preference in the event of bank failure. ${ }^{17}$ For simplicity, we abstract from regulatory capital requirements throughout the main analysis, but we do discuss capital requirements in Section 5. Bank operating costs are normalized to zero. There is universal risk-neutrality and no discounting.

\subsection{Lending Setup}

There is a unit mass of penniless entrepreneurs, each of whom requires $\$ 1$ for a project. There also is a unit mass of small retail depositors with aggregate savings of $\$ 1$. Thus, insured deposits are scarce - the bank has access to only $\$ 1$ of them-but they are sufficient to fund entrepreneurs' projects. Entrepreneurs can finance their projects with bank loans or corporate bonds. ${ }^{18}$ Corporate bond financing is costly: if an entrepreneur issues corporate bonds, a bond issuance transaction cost $s>0$ must be incurred. No such cost is incurred if the entrepreneur finances her project with a bank loan.

Entrepreneurs are endowed with identical projects that either succeed or fail at matu-

\footnotetext{
${ }^{16}$ Fair deposit insurance pricing will be considered later on.

${ }^{17}$ Furthermore, we assume that banks cannot pay interim dividends. This excludes the possibility of outright depositor expropriation by selling assets and paying out the proceeds as dividends.

${ }^{18}$ Raising funds directly from retail depositors is prohibitively costly or simply not feasible.
} 
rity. In the event of project success, project $i$ generates a gross return $\tilde{\theta} \Pi$, where $\tilde{\theta} \in[0,1]$ represents macroeconomic uncertainty and $\Pi>0$ is a constant. The macroeconomic shock $\tilde{\theta}$ is distributed according to a smooth c.d.f. $F(\theta)$ with $F(0)=0, F(1)=1$, and $F^{\prime}(\theta)>0$ for all $\theta \in(0,1)$. Let $\int \theta d F(\theta)=\mu$. In the event of project failure, the gross return is zero. The probability of project success is idiosyncratic and depends upon entrepreneur $i$ 's unobservable (and, hence, non-contractible) effort: if the entrepreneur exerts effort $e_{i} \in[0,1]$, then the probability of project success is $e_{i}$. There is a private effort cost $\psi\left(e_{i}\right)$ that is increasing and strictly convex and satisfies $\psi(0)=\psi^{\prime}(0)=0, \psi^{\prime}(1) \geq \mu \Pi$, and $\psi^{\prime \prime \prime}\left(e_{i}\right) \geq 0$. We assume that project NPV is positive in the absence of financial frictions:

$$
\max _{e_{i}}\left\{e_{i} \mu \Pi-\psi\left(e_{i}\right)\right\}>1
$$

For later reference, let $e^{F B}$ denote the project value maximizing ("first best") effort level. The first best effort level is characterized by the first order condition $\mu \Pi-\psi^{\prime}\left(e_{i}\right)=0$.

The timing is as follows. At date 0, the bank collects deposits (and potentially issues other securities) and quotes a gross loan rate $R$. Entrepreneurs subsequently decide whether to finance their projects with bank loans or corporate bonds. Once projects are undertaken, entrepreneurs exert effort. At date 1, project returns realize and payments are made.

Financial markets are assumed to be competitive. That is, competitive pressure forces the bank to charge a loan rate such that it just breaks even on its lending activities (e.g., because of the threat of entry by competing banks sitting on the sidelines). Other types of investors (bond investors and, as far as banks are concerned, depositors) are willing to finance entrepreneurs and banks as long as they can expect to break even, and competitive pressure forces them to accept returns such that they just break even. 


\subsection{Equilibrium in the Absence of Trading Opportunities}

Throughout the analysis, we assume that the underlying parameter constellations and functional forms are such that an equilibrium with real investment exists and that investment is socially efficient. ${ }^{19}$ We abstract from deadweight costs of deposit insurance underpricing (such as efficiency distortions due to taxation), other than its potentially negative effect on incentives and financial stability. The key welfare distortion of interest stems from entrepreneurs' potential incentive to deviate from efficient effort.

Consider an equilibrium with bank loan financing. For a given gross loan rate $R>0$, entrepreneur $i$ defaults with probability one in the event of project failure (probability $\left.1-e_{i}\right)$ and with probability $\operatorname{Prob}[\tilde{\theta} \Pi<R]=F(R / \Pi)$ in the event of project success (probability $e_{i}$ ). Thus, given that entrepreneurs are identical and exert the same effort level $e$ in equilibrium, the corporate default rate is

$$
\sigma_{E}=e F(R / \Pi)+1-e
$$

This is increasing in the loan rate due to the direct effect on the probability of default in the event of project success and the indirect effect on entrepreneurs' incentive to exert effort (as we shall see below, higher loan rates entail lower effort). ${ }^{20}$ In the event of default, the bank seizes project returns. Otherwise, entrepreneur $i$ receives the project return $\theta \Pi$ and pays $R$ to the bank. Thus, entrepreneur $i$ 's payoff function is

$$
U_{E}(e, R)=e \int_{R / \Pi}^{1}(\theta \Pi-R) d F(\theta)-\psi(e)
$$

Next, consider the bank. By the law of large numbers, the bank's loan portfolio generates revenue $\min [e \theta \Pi, e R]$ with probability one, conditional on $\theta$. It will become clear below that the bank has no incentive to secure funds in the wholesale market, in addition to accepting $\$ 1$ of insured retail deposits. Hence, the bank defaults if and only if

\footnotetext{
${ }^{19}$ We will come back to this in Section 5 .

${ }^{20}$ The pairwise correlation between defaults is $e F(R / \Pi) / \sigma_{E}$. This depends endogenously on $e$ and $R$.
} 
$\min [e \theta \Pi, e R]<1$. We assume that the bank is willing to engage in lending only if it does not fail with probability one. Since $e R \geq 1$ in an equilibrium in which the bank does not fail with probability one, the preceding expression reduces to $e \theta \Pi<1$ or $\theta<1 /(e \Pi) \equiv \hat{\theta}$. Hence, the bank's failure rate is $\sigma_{B}=F(1 /(e \Pi))$. In the event of bank failure, the deposit insurance agency seizes the bank's revenue. Thus, the bank's profit is

$$
U_{B}(e, R)=\int_{\hat{\theta}}^{R / \Pi}(e \theta \Pi-1) d F(\theta)+\int_{R / \Pi}^{1}(e R-1) d F(\theta)
$$

This can be rewritten as

$$
U_{B}(e, R)=\underbrace{\int_{0}^{R / \Pi} e \theta \Pi d F(\theta)+\int_{R / \Pi}^{1} e R d F(\theta)-1}_{\text {NPV lending business }}+\underbrace{\int_{0}^{\hat{\theta}}(1-e \theta \Pi) d F(\theta)}_{\text {safety-net subsidy }}
$$

The first term is the bank's profit from lending before subsidies from underpriced deposit insurance. The second term is the subsidy from government-funded deposit insurance. With government-funded deposit insurance, the state, rather than the bank, pays for deposit insurance premia. This results in a reduction of the bank's funding cost relative to a system with fair deposit insurance pricing. The deposit insurance agency's loss (it pays $\$ 1$ in bank failure states and receives $e \theta \Pi<1)$ is, then, the bank's gain.

The loan market equilibrium maximizes entrepreneurs' surplus. It solves the following optimization problem:

$$
\begin{array}{ll}
\max _{(e, R)} & U_{E}(e, R)=e \int_{R / \Pi}^{1}(\theta \Pi-R) d F(\theta)-\psi(e) \\
\text { s.t. } & \\
& U_{B}(e, R)=0 \\
& \partial U_{E}(e, R) / \partial e=\int_{R / \Pi}^{1}(\theta \Pi-R) d F(\theta)-\psi^{\prime}(e)=0
\end{array}
$$

where (IR) is the bank's zero profit constraint - in equilibrium, the bank must be indifferent between lending and not lending - and (IC) is entrepreneur $i$ 's incentive constraint. 
The bank's break even constraint yields $R(e)=1 / e$. Substituting for the loan rate, the problem reduces to

$$
\max _{e} \quad U_{E}(e, R(e))=\underbrace{e \mu \Pi-\psi(e)-1}_{\text {project NPV }}+\int_{0}^{\hat{\theta}}(1-e \theta \Pi) d F(\theta)
$$

s.t.

$$
\mu \Pi-\underbrace{\frac{1-\overbrace{\int_{0}^{\hat{\theta}}(1-e \theta \Pi) d F(\theta)}^{\text {safety-net subsidy } \in(0,1)}}{e}}_{\text {expected debt burden }} \psi^{\prime}(e)
$$

where $\hat{\theta}=1 /(e \Pi)$ and (IC') is the reduced form incentive constraint. Thus, as is standard in competitive lending settings with borrower moral hazard, the problem boils down to maximizing the joint surplus subject to incentive-compatibility. The left hand side of (IC') is entrepreneur $i$ 's payoff in the event of project success. This is the difference between the expected project return and the expected debt burden in the event of project success. Notice that while the safety-net subsidy initially accrues to the bank, it is ultimately passed on to entrepreneurs in the form of a lower loan rate. To ensure that the optimization problem is well-behaved, we assume in what follows that the parameter values and functional forms are such that $U_{E}(e, R(e))$ is strictly concave over the relevant range. ${ }^{21}$ We have the following benchmark result:

Proposition 1 Suppose that the bank can engage in deposit taking and lending, but not in trading. Then, equilibrium effort under bank loan financing, denoted by $e^{*}$, is given by the largest solution of (IC') and is strictly inferior to first best effort $e^{F B}$. The corporate default rate is $\sigma_{E}^{*}=e^{*} F\left(1 /\left(e^{*} \Pi\right)\right)+1-e^{*}$ and the bank's failure rate is $\sigma_{B}^{*}=F\left(1 /\left(e^{*} \Pi\right)\right)$.

\footnotetext{
${ }^{21}$ The second derivative of $U_{E}(e, R(e))$ is $-\psi^{\prime \prime}(e)+\hat{\theta}^{2} f(\hat{\theta}) \Pi / e$, where the second term is due to deposit insurance. Assuming strict concavity, thus, amounts to assuming that $\psi^{\prime \prime}(e)$ exceeds the second term.
} 
Notice that the unconstrained optimum - that is, the effort level that is jointly efficient for the bank and entrepreneurs - would be characterized by

$$
U_{E}^{\prime}(e, R(e))=\underbrace{\mu \Pi-\psi^{\prime}(e)}_{\text {first best society }}-\int_{0}^{\hat{\theta}} \theta \Pi d F(\theta)=0
$$

where the second term is the marginal safety-net subsidy. Thus, subsidized deposit insurance entails a distortion of the jointly efficient effort level relative to what is socially optimal. Crucially, however, even though deposit insurance subsidies entail a distortion of the unconstrained optimum, they have a positive effect on equilibrium effort. As mentioned, the reason is that the incremental safety-net subsidy from real investment is passed on to entrepreneurs in the form of lower loan rates, thus lowering their debt burden and making it more worthwhile for them to exert effort. Notice, too, that the bank has no incentive to raise additional funds in the wholesale funding market. Due to depositor preference, doing so would only result in a reduction of the safety-net subsidy.

The preceding discussion suggests that fair deposit insurance pricing would be detrimental to welfare in our economy. With fair deposit insurance pricing, the bank would be charged a premium $P$ such that deposit insurance does not involve a subsidy to the bank. Let us assume that the bank's loan pricing is observable to the deposit insurance agency and suppose that the premium is due ex post. The bank's profit function becomes

$$
U_{B}(e, R)=\int_{\hat{\theta}}^{R / \Pi}(e \theta \Pi-(1+P)) d F(\theta)+\int_{R / \Pi}^{1}(e R-(1+P)) d F(\theta)
$$

where $\hat{\theta}=(1+P) /(e \Pi)$. The deposit insurance agency's zero profit constraint is

$$
\int_{0}^{\hat{\theta}}(1-e \theta \Pi) d F(\theta)=\int_{\hat{\theta}}^{1} P d F(\theta)
$$

Substituting for this expression, it is straightforward to see that the reduced form optimization problem is identical to the reduced form problem with subsidized deposit insurance, except that the safety-net subsidy vanishes. Hence, the following result: 
Corollary 1 With fair deposit insurance pricing, equilibrium effort under bank loan financing, $e^{\text {fair }}$, is given by the largest solution of

$$
\mu \Pi-1 / e=\psi^{\prime}(e)
$$

and is strictly inferior to $e^{*}$. Thus, in the absence of trading opportunities, fair deposit insurance pricing is suboptimal. Specifically, fair deposit insurance pricing would have negative implications for both corporate sector efficiency and banking system stability $\left(\sigma_{B}\right)$.

Reiterating the intuition, in a competitive lending market, the incremental safety-net subsidy from real investment is passed on to the corporate sector in the form of lower loan rates. This has positive implications for incentives and welfare.

The obvious caveat is that the desirability of subsidized deposit insurance may hinge on our assumption that deposit insurance underpricing has no deadweight costs other than its potentially negative effect on incentives (here, of course, the incentive effect is positive). If taxation had substantial deadweight costs, there would be a tradeoff between minimizing the deadweight costs of financing deposit insurance subsidies through taxation and maximizing financial stability and corporate sector efficiency. Likewise, if deposit insurance subsidies undermined banks' operating efficiency (e.g., by making it less worthwhile to uncover cost savings), subsidized deposit insurance might be counterproductive. ${ }^{22}$

Let us conclude this section by analyzing the case of bond financing. With bond financing, entrepreneurs need to borrow an extra amount $s$ to finance the bond issuance transaction cost, and there is no safety-net subsidy. Thus, the following:

Corollary 2 Equilibrium effort under bond financing, $e^{\text {bond }}$, is given by the largest solution of

$$
\mu \Pi-(1+s) / e=\psi^{\prime}(e)
$$

\footnotetext{
${ }^{22} \mathrm{~A}$ more fundamental issue has to do with the question of why subsidies are given in the form of debt guarantees and not directly (cf., Admati et al. 2010). We will come back to this in Section 5.
} 
and is strictly inferior to $e^{*}$ and $e^{\text {fair }}$. Thus, in the absence of trading opportunities, bank loan financing strictly dominates bond financing.

In our setup, bond financing is inefficient for two reasons. First, it is costlier than bank loan financing as it involves the transaction cost $s$. This entails an increase in entrepreneurs' debt burden relative to bank loan financing (even with fair deposit insurance pricing), which reduces their incentive to exert effort. Second, corporate bonds do not benefit from subsidized deposit insurance, which gives rise to an additional incentive distortion. For later reference, let $R^{\text {bond }}$ denote the promised gross return under bond financing.

\section{3 "Pure" Proprietary Trading: Gambling}

We now introduce proprietary trading. We start with the case of socially useless, purely speculative trading that it is unrelated to client or bank hedging needs and whose only purpose is to exploit the taxpayer funded safety net. We refer to this as "gambling".

\subsection{Gambling Technology}

There is a continuum of gambling activities (e.g., FX trading, equity trading, derivatives trading, CDO structuring and trading, etc.), indexed by $g \in[1, \bar{g}]$ with $\bar{g}>1$, and each requiring an upfront cash outlay of $\$ 1$. At date 0 , the bank has the opportunity to pick, at most, one of these activities. ${ }^{23}$ Gambling activity $g$ generates a gross return $g$ if and only if macroeconomic conditions are favorable, $\tilde{\theta} \geq \theta(\mathrm{g})$, and zero otherwise.

Gambling involves placing bets in financial markets. We consider arbitrage-free markets

\footnotetext{
${ }^{23}$ In fact, we assume that the bank can either invest $\$ 1$ in trading or stay inactive. This assumption is inessential, though, and could be dispensed with at the expense of complicating the exposition.
} 
where securities are fairly priced. Thus, gambling, in itself, is a zero NPV activity-i.e.,

$$
\int_{\theta(g)}^{1} g d F(\theta)=1
$$

and, hence, $[1-F(\theta(g))] g=1$ for all $g$. In other words, $\theta(g)$ is strictly increasing in $g$ and $\theta(1)=0$. As mentioned, we assume that gambling is of no value to society. ${ }^{24}$

The gambling upper bound $\bar{g}$ may stem from regulatory bank activity restrictions. When activity restrictions are lax ( $\bar{g}$ high), banks can engage in riskier activities. Alternatively, $\bar{g}$ could be a proxy for financial deepening. It seems plausible that banks can take riskier bets when financial markets are deeper and more developed.

Suppose, now, that the bank collects $\$ 1$ of insured deposits and devotes them to gambling. Furthermore, suppose that the bank does not engage in lending (if it did, it would have to raise additional funds in the wholesale market). For $\tilde{\theta}<\theta(g)$, gambling yields a return of zero and the bank fails. Depositors are then bailed out by the deposit insurance agency. For $\tilde{\theta} \geq \theta(g)$, gambling generates revenues $g$, out of which the bank pays $\$ 1$ to depositors. Thus, the bank's profit is

$$
\int_{\theta(g)}^{1}(g-1) d F(\theta)=\int_{0}^{\theta(g)} d F(\theta)=F(\theta(g))
$$

As gambling, in itself, has zero NPV, the bank's profit from gambling is given by the safety-net subsidy under gambling. This is strictly increasing in $g$. Thus, the bank takes the riskiest gamble possible, $g=\bar{g}$, and derives a profit of $F(\theta(\bar{g}))=1-1 / \bar{g}>0$.

\subsection{Equilibrium}

We now construct the loan market equilibrium. Notice that the bank's payoff from not lending is no longer zero; it is given by its profit from stand-alone gambling, $F(\theta(\bar{g}))>0$. The bank is willing to lend if and only if its overall payoff from lending (and, perhaps,

\footnotetext{
${ }^{24}$ In practice, trading may, of course, create value for society very well; see the next section.
} 
additional gambling) is not smaller than its payoff from stand-alone gambling. Competitive pressure in the loan market forces the bank to charge a loan rate $R$ such that it is just indifferent between lending and stand-alone gambling. Entrepreneurs prefer bank loan financing over bond financing if and only if $R<R^{\text {bond }} \cdot{ }^{25}$ In the case of indifference, we assume that entrepreneurs seek bond financing. Now consider a candidate equilibrium in which the bank engages in lending. Will the bank also engage in gambling?

Lemma 1 If in equilibrium the bank engages in lending, it will not engage in gambling.

Intuitively, since gambling is a zero NPV activity, and wholesale investors, being rational, cannot make losses in expectation, gambling can create value for the bank only if it results in a higher safety-net subsidy than lending alone would do. Due to depositor preference, however, this will not be the case. Relative to the lending-only scenario, gambling either results in no additional revenue or in additional revenue $g$. In the event of bank failure, the deposit insurance subsidy seizes the bank's revenue and uses it, first, to satisfy depositors' claims (the residual, if positive, accrues to wholesale investors). Thus, the additional income brought in by gambling either lowers the deposit insurance agency's losses or leaves them unaltered. Therefore, while gambling in addition to lending may raise the likelihood of bank failure relative to the lending-only scenario, it will not result in an additional transfer of wealth from the safety net to bank shareholders. In many cases, gambling would actually reduce the wealth transfer from the safety net. To see this, suppose that gambling were a riskless activity $(\bar{g}=1)$. "Gambling" would then be equivalent to raising $\$ 1$ of equity capital and keeping the proceeds as cash. The bank would never fail and, hence, the safety-net subsidy would be zero.

\footnotetext{
${ }^{25}$ In principle, entrepreneurs could seek bank loan financing from other banks. However, to the extent that banks are identical, other banks would quote the same rate as our representative bank.
} 
As the bank does not lend and gamble, an equilibrium with lending is characterized by the solution to the following optimization problem:

$$
\begin{array}{ll}
\max _{(e, R)} & U_{E}(e, R)=e \int_{R / \Pi}^{1}(\theta \Pi-R) d F(\theta)-\psi(e) \\
\text { s.t. } & \\
& U_{B}(e, R)=1-1 / \bar{g} \\
& \partial U_{E}(e, R) / \partial e=0
\end{array}
$$

where $\hat{\theta}=1 /(e \Pi)$, as before. This problem is identical to the problem without proprietary trading, except that now the bank will have to be compensated for the profit that it gives up when it devotes scarce insured deposits to lending rather than to gambling.

Substituting for (IR), the problem reduces to

$$
\begin{array}{ll}
\max _{e} & U_{E}(e, R(e))=\underbrace{e \mu \Pi-\psi(e)-1}_{\text {project NPV }}+\int_{0}^{\hat{\theta}}(1-e \theta \Pi) d F(\theta)-[1-1 / \bar{g}] \\
\text { s.t. } & \\
& \mu \Pi-\frac{1-\int_{0}^{\hat{\theta}}(1-e \theta \Pi) d F(\theta)+[1-1 / \bar{g}]}{e}-\psi^{\prime}(e)=0
\end{array}
$$

The first term in the objective function is project NPV; the second term is the safety-net subsidy from lending; and the third term is the safety-net subsidy from gambling. When devoting scarce insured deposits to lending, the bank will have to be compensated for its lost gambling profits. This raises entrepreneurs' debt burden, which, in turn, reduces their incentive to exert effort. Thus, the mere possibility to engage in gambling can give rise to a welfare distortion, even if, in equilibrium, the bank does not engage in gambling and even though gambling, in itself, is not inefficient.

The question remains whether entrepreneurs prefer bank loan financing over bond financing. Let $e^{* *}$ denote the equilibrium effort level under bank loan financing (i.e., the largest solution of (ICG)) and $R^{* *}$ the corresponding loan rate. Entrepreneurs prefer bank loan financing if and only if $R^{* *}<R^{\text {bond }}$. This will be the case if and only if the expected 
debt burden under bank loan financing is lower than the expected debt burden under bond financing. ${ }^{26}$ Rearranging terms, this amounts to

$$
\int_{0}^{\hat{\theta}}\left(1-e^{* *} \theta \Pi\right) d F(\theta)-[1-1 / \bar{g}]>-s
$$

The left hand side of this expression is the incremental safety-net subsidy from lending. This is positive when gambling is relatively safe and negative when gambling is relatively risky. The right hand side stems from the bond issuance transaction cost. Notice that (3) holds for all $s \geq 0$ if the incremental safety-net subsidy is positive. This will be the case if activity restrictions are relatively tight ( $\bar{g}$ close to one). For relatively lax activity restrictions ( $\bar{g}$ high), however, entrepreneurs may prefer bond financing:

Proposition 2 Suppose that the bank can engage in gambling. Then:

(i) If bank activity restrictions are relatively tight; i.e.,

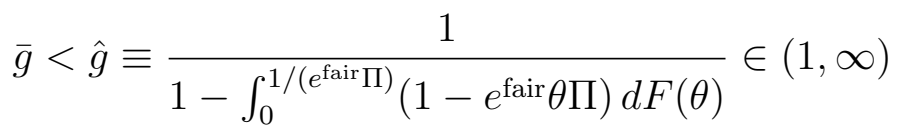

where $e^{\text {fair }}$ is the effort level under fair deposit insurance pricing, then bank loan financing dominates bond financing for all s. In equilibrium, entrepreneurs are financed with bank loans and exert effort $e^{* *}<e^{*}$.

(ii) Conversely, if bank activity restrictions are relatively lax, $\bar{g} \geq \hat{g}$, then there is a bond issuance transaction cost threshold $\hat{s}$ such that:

(a) For $s>\hat{s}$ (high bond issuance transaction costs), entrepreneurs are financed with bank loans and exert effort $e^{* *}<e^{*}$.

\footnotetext{
${ }^{26}$ Entrepreneurs prefer bank loan financing if and only if $U_{E}\left(e^{* *}, R^{* *}\right)>U_{E}\left(e^{\text {bond }}, R^{\text {bond }}\right)$, which is equivalent to $R^{* *}<R^{\text {bond }}$ by (IC), and, substituting for investors' binding IR constraints, reduces to

$$
\int_{e^{\text {bond }}}^{e^{* *}} \mu \Pi-\psi^{\prime}(e) d e+\int_{0}^{\hat{\theta}}\left(1-e^{* *} \theta \Pi\right) d F(\theta)-[1-1 / \bar{g}]>-s
$$

Yet $e^{\text {bond }}<e^{* *}$ if and only if (3) holds, and, hence, (2) holds if and only if (3) holds. 


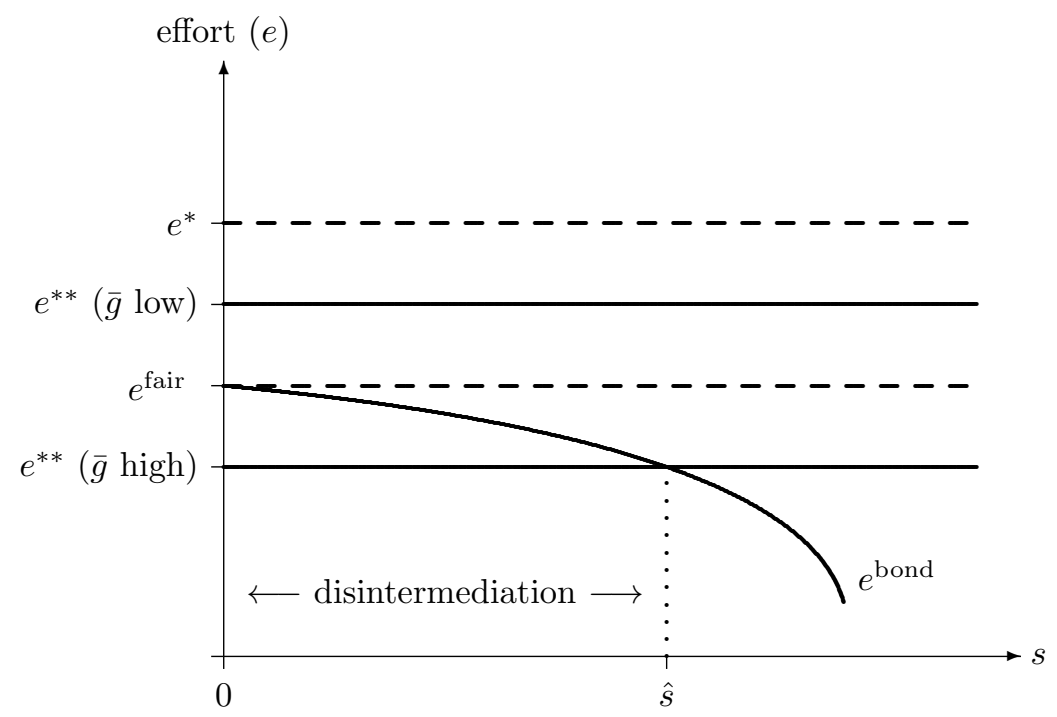

The curved line depicts effort under bond financing $\left(e^{\text {bond }}\right)$. For $s=0$, this coincides with the effort level under bank loan financing with fair deposit insurance pricing ( $\left.e^{\text {fair }}\right)$. It is inferior to the effort level under bank loan financing with subsidized deposit insurance in the absence of proprietary trading $\left(e^{*}\right)$. When activity restrictions are tight $(\bar{g}$ low), effort under bank loan financing $\left(e^{* *}\right)$ exceeds effort under bond financing. When activity restrictions are lax ( $\bar{g}$ high), effort under bank loan financing exceeds $e^{\text {bond }}$ if and only if the bond issuance transaction cost is sufficiently high. If so, entrepreneurs are financed with bank loans. For $s \leq \hat{s}$, entrepreneurs finance their projects with corporate bonds (disintermediation).

Figure 1: Bank Loan vs. Bond Financing

(b) For $s \leq \hat{s}$ (low bond issuance transaction costs), the bank does not engage in lending and focuses on proprietary trading. Entrepreneurs issue corporate bonds at cost $s$ and exert effort $e^{\text {bond }}<e^{*}$.

Thus, when activity restrictions are lax and bond issuance transaction costs are low, the equilibrium exhibits disintermediation: entrepreneurs are financed with corporate bonds and the bank focuses on proprietary trading. ${ }^{27}$ Intuitively, when activity restrictions are

\footnotetext{
${ }^{27}$ The result that the bank is totally inactive in lending should not be taken too literally. If there were heterogeneity among entrepreneurs - e.g., with respect to the bond issuance transaction cost- some might
} 
lax, stand-alone gambling is highly lucrative for the bank. As entrepreneurs would have to compensate the bank for giving up gambling profits, they are better off under bond financing if the corresponding transaction cost is not too high. Conversely, when activity restrictions are tight or bond issuance is subject to high transaction costs, they are better off under bank loan financing. The bank is active in lending and abstains from gambling. The possibility of engaging in gambling trading still entails a welfare distortion. This is because it makes corporate loans more costly, thus stifling incentives. Figure 1 provides an illustration.

\subsection{Financial Stability}

We next analyze the effect of gambling opportunities on the bank's failure rate and credit risk. Recall that $\sigma_{B}^{*}=F\left(1 /\left(e^{*} \Pi\right)\right)$ is the bank's failure rate in the absence of gambling opportunities; and let $\sigma_{B}^{\mathrm{gbl}}=1-1 / \bar{g}$ denote the failure rate when the bank gambles and $\sigma_{B}^{* *}=F\left(1 /\left(e^{* *} \Pi\right)\right)$ the failure rate when it lends but could gamble.

Clearly, $\sigma_{B}^{* *}>\sigma_{B}^{*}$ for all $\bar{g}>1$ since $e^{* *}<e^{*}$. In other words, if in equilibrium the bank abstains from gambling, then the opportunity to engage in gambling has negative implications for financial stability. However, if in equilibrium the bank engages in gambling, then its failure rate does not necessarily exceed the failure rate in the absence of gambling opportunities. To see this, notice that the equilibrium exhibits gambling if and only if (3) does not hold; i.e.,

$$
\int_{0}^{1 /\left(e^{* *} \Pi\right)}\left(1-e^{* *} \theta \Pi\right) d F(\theta)+s \leq 1-1 / \bar{g}=\sigma_{B}^{\mathrm{gbl}}
$$

be financed with bank loans and others might seek bond financing. The key message is that the presence of zero NPV trading opportunities makes bank loans more costly, inducing at least some entrepreneurs to seek costly bond financing (which they would not do in the absence of trading opportunities). 
Thus, in a gambling equilibrium,

$$
\sigma_{B}^{*}<\sigma_{B}^{* *}=\int_{0}^{1 /\left(e^{* *} \Pi\right)} d F(\theta) \leq \sigma_{B}^{\mathrm{gbl}}+\underbrace{\int_{0}^{1 /\left(e^{* *} \Pi\right)} e^{* *} \theta \Pi d F(\theta)}_{\text {recovery amount }}-s
$$

Consequently, for some parameter constellations, it could be the case that the failure rate in the absence of gambling opportunities exceeds the failure rate in a gambling equilibrium: $\sigma_{B}^{*}>\sigma_{B}^{\text {gbl }}$. The reason that this is so (apart from the obvious - but still crucial-fact that lending can be a risky activity, too) is that for a given probability of default, the safety-net subsidy under gambling exceeds the safety-net subsidy under lending. This is because, under lending, the recovery rate in the event of bank default is positive, while under gambling, it is zero. If the recovery rate were negligible, then the bank's failure rate in a gambling equilibrium would exceed its failure rate in the absence of gambling opportunities. If not, then this result might not hold.

While the introduction of gambling opportunities can, for some parameter constellations, reduce the bank's probability of default provided that the bank, indeed, gambles in equilibrium, it has an unambiguously adverse effect on credit risk. Let us define credit risk as the deposit insurance agency's expected losses from bank default. This, of course, is the safety-net subsidy. Thus, by (4), credit risk in the presence of gambling opportunities always exceeds credit risk in their absence. To summarize:

\section{Corollary 3}

(i) (probability of default) If in equilibrium the bank abstains from gambling, then the opportunity to gamble will raise the bank's failure rate. Conversely, if in equilibrium the bank gambles, the bank's failure rate in the presence of gambling opportunities may or may not exceed its failure rate in the absence of gambling opportunities.

(ii) (credit risk) The opportunity to gamble always has an adverse impact on the bank's credit risk, regardless of whether the bank gambles in equilibrium. 


\subsection{Policy Options}

We conclude with an analysis of policy options, starting with the following observation:

Corollary 4 (Volcker Rule) Banks should be prohibited from gambling: $\bar{g}=1$.

While the objective of the Volcker Rule - curbing socially useless speculative trading at safety net protected banks - is laudable, the key difficulty is that it might be difficult to enforce and have undesirable unintended consequences (cf., Duffie 2012a; Thakor 2012). ${ }^{28}$ Banks may be able to hide trading or disguise it as lending. Even if trading exposures can be observed or inferred from market prices, it may be very difficult for regulators to assess whether such exposures stem from pure "speculation" or permissible market making or risk management related activities. ${ }^{29}$ An outright prohibition of speculative trading can have undesirable consequences in this environment. Banks may devote resources to hiding trading, and they may abstain from value-enhancing trading, fearing that it will be mixed up with non-permissible speculation and punished as such. The provision of market making and risk management services may then migrate to the unregulated shadow banking sector, with potentially adverse systemic consequences. Thus, there is some interest in exploring the effectiveness of policy measures other than trading prohibitions. We discuss (i) fair deposit insurance pricing; (ii) facilitating securitization; and (iii) ring-fencing.

Fair Deposit Insurance Pricing. With fair deposit insurance pricing, the bank is charged a premium such that deposit insurance does not involve a subsidy to the bank. Standalone gambling is, then, no longer profitable for the bank: the bank's reservation payoff

\footnotetext{
${ }^{28}$ Of course, regulators are well aware of implementation issues. See Chow and Surti (2011) for an excellent overview of the various approaches and remedies that are under discussion.

${ }^{29}$ For example, consider the trading losses incurred by JP Morgan's Chief Investment Office in April and May 2012. It was and still is unclear whether these losses stemmed from insane speculation or hedging that "just" went wrong. See the coverage at the Financial Times' Alphaville blog.
} 
from not lending is zero. To make this more precise, let us consider the following setup. At date 0 , the bank decides whether to be active in trading. This decision is observable to the regulator. The bank's actual risk choice $(g)$ may or may not be observable to the regulator - we will see that it does not matter. The regulator also observes the bank's lending, including its loan pricing. After having observed the bank's activity choice, the regulator sets the deposit insurance premium, due at date 1 . The premium is set such that, in expectation, the deposit insurance agency just breaks even.

Suppose, now, that the bank invests in gambling but stays inactive in lending. Then, if the bank's risk choice $g$ is observable, the premium $P(g)$ will reflect its risk choice, and the bank's profit from gambling is

$$
\int_{\theta(g)}^{1}(g-1-P(g)) d F(\theta)
$$

where $\int_{\theta(g)}^{1} P(g) d F(\theta)=\int_{0}^{\theta(g)} d F(\theta)$. In other words, $P(g)=g-1$ and the bank's profit from gambling is zero for all $g$. Conversely, if the bank's risk choice is not observable, then $g=\bar{g}$ and $P=\bar{g}-1$ in a gambling subgame. Thus, regardless of whether or not the bank's risk choice is observable, the bank's profit from gambling is zero.

In equilibrium, entrepreneurs will be financed with bank loans and exert effort $e^{\text {fair }}<e^{*}$. In terms of its implications for allocative efficiency, this is equivalent to a policy regime with subsidized deposit insurance and a gambling restriction $\bar{g}=\hat{g}$ (see Proposition 2). Both implement effort $e^{\text {fair }}$ and no gambling in equilibrium. Yet fair deposit insurance pricing does not entail wealth transfers from the taxpayer, and, thus, may be deemed superior. At any rate, a regime with subsidized deposit insurance and an activity restriction $\bar{g}<\hat{g}$ would be, in terms of efficiency, superior to a regime with fair deposit insurance pricing.

Proposition 3 If activity restrictions $\bar{g}<\hat{g}$ are feasible, then a policy regime with subsidized deposit insurance in conjunction with an activity restriction $\bar{g}$ outperforms a regime with fair deposit insurance pricing. Otherwise, the optimal policy regime involves fair de- 
posit insurance pricing. Fair deposit insurance pricing implements an equilibrium with bank loan financing, no gambling, and entrepreneurial effort $e^{\text {fair }}$.

Thus, while suboptimal in the absence of gambling opportunities, fair deposit insurance pricing can improve welfare in the presence of gambling opportunities. This will be the case when relatively tight activity restrictions, $\bar{g}<\hat{g}$, are too costly or not feasible.

Above, we have implicitly assumed that the degree to which deposit insurance is fairly priced (or subsidized) cannot be made contingent on the bank's activity choice. If this were feasible, the optimal policy would involve fair deposit insurance pricing when the bank engages in gambling and subsidized deposit insurance when it does not. Such a policy would implement the equilibrium in the absence of trading opportunities: gambling would be deterred, and deposit insurance subsidies would be efficiently used to support the real economy. We will come back to this below.

Securitization. In our preceding analysis, we have assumed that insured depositors have preference in the event of bank failure. The effect of this is that, conditional on lending, it is not profitable for the bank to engage in gambling. This can be costly since in a lending equilibrium, the corporate sector will have to compensate the bank for its lost gambling profits. If the bank could be induced to lend and gamble in equilibrium and if doing so allowed it to extract more from the safety net than lending alone would allow for, corporate loan rates might be reduced and efficiency improved. We will now illustrate how this can be achieved through securitization.

Suppose that the bank collects $\$ 1$ of insured deposits, invests them in entrepreneurial loans, and charges a loan rate $R^{\text {fair }}$ (i.e., the equilibrium loan rate with fair deposit insurance pricing). Thus, the loan portfolio is worth

$$
\int_{0}^{R^{\text {fair }} / \Pi} e^{\text {fair }} \theta \Pi d F(\theta)+\int_{R^{\text {fair }} / \Pi}^{1} e^{\text {fair }} R^{\text {fair }} d F(\theta) \equiv 1
$$


Once having originated the loans, the bank sells them to a special purpose vehicle (SPV) at fair value (\$1). The SPV finances itself by issuing wholesale securities, and it is bankruptcyremote - i.e., the bank's creditors (depositors) have no claim on the SPV's cash flows. This constitutes an implicit violation of depositor preference: deposits are de facto subordinated to wholesale securities. The bank subsequently invests the proceeds from the loan portfolio sale $(\$ 1)$ in gambling. Its profit is $1-1 / \bar{g}$ : precisely the profit it would have made if it had engaged in stand-alone gambling.

The question remains whether and when this is an equilibrium. Two conditions must be fulfilled: (i) the safety-net subsidy from lending only must not exceed the safety-net subsidy from securitization and gambling; and (ii) the posited loan rate $R^{\text {fair }}$ cannot be undercut-i.e., the bank would make losses if it charged a loan rate $R<R^{\text {fair }}$. The first condition will be satisfied if and only if gambling is a relatively risky activity, $\bar{g}>\hat{g}$. To see that $R^{\text {fair }}$ cannot be undercut, note that if the bank charged a lower rate, the value of its loan portfolio and, hence, the proceeds raised through securitization would be lower than one. The bank may then raise additional wholesale funds and invest $\$ 1$ in gambling, but, in any case, its profit from doing so would be less than the profit from stand-alone gambling. In other words, the bank would not break even. To summarize:

Proposition 4 Suppose that the bank can lend, gamble, and securitize. Then, entrepreneurs are always financed with bank loans. Furthermore:

(i) For $\bar{g} \leq \hat{g}$ (Proposition 2), the bank does not engage in securitization and entrepreneurs exert effort $e^{* *} \geq e^{\text {fair }}$. The bank's failure rate is $\sigma_{B}^{* *}=F\left(1 /\left(e^{* *} \Pi\right)\right)$.

(ii) For $\bar{g}>\hat{g}$, the bank quotes a loan rate $R^{\text {fair }}$, lends, securitizes loans, and gambles. Entrepreneurs exert effort $e^{\mathrm{fair}}>e^{* *}$. The bank's failure rate is $\sigma_{B}^{\mathrm{gbl}}=1-1 / \bar{g}$.

Thus, securitization weakly improves corporate efficiency relative to the no-securitization benchmark, at the expense of weakly increasing the bank's credit risk. 
Securitization enables the bank to extract precisely the same subsidy that it would extract under stand-alone gambling. When gambling is relatively risky $(\bar{g}>\hat{g})$, this exceeds the subsidy from lending only. The incremental subsidy from lending is, therefore, zero rather than negative, and, consequently, loan rates will be lower and lending efficiency higher relative to the no-securitization benchmark. The flip side of this is that the bank's credit risk will be higher (provided that, in the absence of securitization, the bank lends rather than gambles). Thus, if activity restrictions $\bar{g} \leq \hat{g}$ are not feasible or too costly, allowing the bank to engage in securitization can improve corporate efficiency, albeit at the expense of (potentially) raising credit risk. At any rate, notice that securitization never outperforms fair deposit insurance pricing.

Ring-Fencing. Above, we alluded to the possibility of making the degree to which deposit insurance is subsidized contingent on the bank's activity choice. If doing so were feasible, the optimal policy would involve fair deposit insurance pricing in the case of gambling and subsidized deposit insurance in the case of lending. Gambling would be deterred, and safety-net subsidies would be efficiently deployed in the real sector. Another way to achieve the same outcome would be to ring-fence the lending business, along the lines of recent policy proposals (Vickers et al. 2011; Liikanen et al. 2012). Banks would be prohibited from funding the trading business with insured deposits, and the lending business would be bankruptcy-remote so that investors financing the trading business would have no claim on the cash flows of the lending business. If feasible, this policy would implement the equilibrium in the absence of trading opportunities. We will come back to ring-fencing in the next section, where we introduce value-enhancing trading opportunities. 


\section{Lending and Trading: Scope Economies}

The next step in our analysis is to introduce value-enhancing trading. Our aim is not to provide a detailed account of channels through which banks' trading can create value for society, ${ }^{30}$ but to focus on one aspect: namely, the provision of treasury and risk management services to corporate borrowers. Having superior information through their lending activities, banks may have a unique advantage in providing such services to their borrowers. Yet, to provide such services, banks may have to take risks and engage in trading.

\subsection{Setup}

We formalize complementarities between lending and trading as follows. As above, there is a continuum $g \in[1, \bar{g}]$ of permissible trading profiles, each requiring an investment of $\$ 1$. The direct returns are as above, and trading in itself has zero NPV. Entrepreneurs value treasury services (e.g., FX hedging and transaction services). Only banks can provide treasury services, and they can do so only if they also establish lending relationships with entrepreneurs. ${ }^{31}$ Provision of treasury services corresponds to a specific trading profile $\check{g}>1$. This trading profile may or may not be permissible: if bank activity restrictions are overly tight, $\bar{g}<\check{g}$, banks will not be able to provide treasury services.

Providing treasury services has real benefits in that it supports entrepreneurs' businesses and improves their operating performance. There are various ways to formalize this. To fix ideas, let us assume that if treasury services are provided, the project return in the event of project failure is no longer zero but $\tilde{\theta} \Delta$, where $\Delta \in(0,1) \cdot{ }^{32}$ Note that since the

\footnotetext{
${ }^{30}$ Trading can be beneficial to a bank's borrowers (see below); clients other than borrowers may value market making and risk management services; and trading may be required for banks' own risk management. Even if trading is purely speculative or comes at the expense of the taxpayer or unsophisticated counterparties, it can create value for society by making financial markets more liquid.

${ }^{31}$ Of course, this could be relaxed; all that matters here is that bank services are complementary.

${ }^{32}$ Alternatively, one could, for example, assume that treasury services generate an additional return $\Delta$
} 
additional return from treasury services is always less than one, and given that the gross loan rate will exceed one in equilibrium, entrepreneurs cannot avoid default in the event of project failure. However, there is additional income in project failure states, thus making debt less risky and, consequently, reducing loan rates.

\subsection{Equilibrium}

Consider a candidate equilibrium in which our representative bank lends and provides treasury services (i.e., $\check{g} \leq \bar{g}$ ). To fund its lending and trading (treasury services) businesses, the bank collects $\$ 1$ of insured deposits and issues an additional $\$ 1$ of wholesale securities. By the law of large numbers, the bank's loan portfolio generates

$$
\min [\theta e \Pi+(1-e) \theta \Delta, e R+(1-e) \theta \Delta]
$$

with probability one, conditional on $\theta$. In addition, the bank's trading strategy generates a direct gross return $\check{g}$ for $\tilde{\theta} \geq \theta(\check{g})$ and zero otherwise. Assuming that $R / \Pi \geq 1 /(e \Pi+$ $(1-e) \Delta)$, and verifying later, the bank's loan portfolio revenue will be sufficient to repay depositors if and only if

$$
\theta \geq \frac{1}{e \Pi+(1-e) \Delta} \equiv \hat{\theta}
$$

In what follows, we say that the treasury services trading profile $\check{g}$ is a high risk trading strategy if and only if $\theta(\check{g}) \geq \hat{\theta}$ and a low risk trading strategy otherwise. We now derive the lending and trading equilibrium, distinguishing between these two cases and assuming in a first step that depositors have universal preference in the event of bank failure and that the government funds deposit insurance.

High Risk Trading Strategy. Suppose that $\check{g}$ is a high risk trading strategy, $\hat{\theta} \leq \theta(\check{g})$. This implies that trading generates a return $\check{g}$ only if the bank's lending revenues are sufficient to repay depositors. Put differently, in states where lending revenues are insufficient in all states; this would not alter the qualitative insights. 
to repay depositors, trading generates a direct return of zero. The bank's trading revenues are "safe": they will not contribute to reducing the deposit insurance agency's losses. Consequently, the safety-net subsidy - i.e., the absolute value of the deposit insurance agency's losses - is given by

$$
S(\Delta)=\int_{0}^{\hat{\theta}}(1-e \theta \Pi-(1-e) \theta \Delta) d F(\theta)
$$

To see this, note that for $\theta<\hat{\theta}$, the bank necessarily fails. The deposit insurance agency seizes what is available, $e \theta \Pi+(1-e) \theta \Delta<1$, and pays $\$ 1$ to depositors. For $\theta \geq \hat{\theta}$, the bank may or may not default (recall that the bank also has a payment obligation vis-àvis wholesale investors). However, the bank's revenue from lending and trading is always sufficient to pay back depositors, and, hence, the deposit insurance agency's loss is zero.

Wholesale investors just break even in equilibrium. Thus, given that trading in itself has zero NPV, the bank's zero profit constraint-keeping the bank indifferent between lending and stand-alone gambling - is

$$
E_{\theta} \min [e \theta \Pi+(1-e) \theta \Delta, e R+(1-e) \theta \Delta]-1+S(\Delta)=1-1 / \bar{g}
$$

where the right hand side is the profit from stand-alone gambling. ${ }^{33}$ Notice that the safetynet subsidy $S(\Delta)$ is decreasing and the bank's overall payoff is increasing in the treasury service return $\Delta$, holding the loan rate constant. Thus, while provision of treasury services entails a lower safety-net subsidy, the bank is more than compensated by the additional return in project failure states. Entrepreneurs exert effort to maximize their payoff

$$
\max _{e} \int_{R / \Pi}^{1} e(\theta \Pi-R) d F(\theta)-\psi(e)
$$

The first order condition is $\int_{R / \Pi}^{1}(\theta \Pi-R) d F(\theta)=\psi^{\prime}(e)$. Substituting for the bank's zero profit constraint from above, the first order condition reduces to

$$
\mu \Pi-\frac{1-S(\Delta)-(1-e) \mu \Delta+[1-1 / \bar{g}]}{e}=\psi^{\prime}(e)
$$

\footnotetext{
${ }^{33}$ Notice that the left hand side of this expression is zero at $R=\Pi /(e \Pi+(1-e) \Delta)$. Hence, we must have $R \geq \Pi /(e \Pi+(1-e) \Delta)$, as posited above.
} 
where the fraction on the left hand side is the expected debt burden. For $\Delta=0$, this coincides with the incentive constraint under gambling, (ICG). An increase in $\Delta$ relaxes (ICT). This is because it makes debt less risky, thus making the bank willing to reduce the loan rate, which, in turn, has positive incentive implications.

We are now in the position to analyze the choice between bank loan and bond financing. As the provision of treasury services requires bank lending, the bond market equilibrium is described by the reduced form incentive constraint

$$
\mu \Pi-(1+s) / e=\psi^{\prime}(e)
$$

Entrepreneurs prefer bank loan financing over bond financing if and only if the expected debt burden under bank loan financing is less than the expected debt burden under bond financing,

$$
(1-e) \mu \Delta+\underbrace{S(\Delta)-[1-1 / \bar{g}]}_{\text {incremental subsidy }}>-s
$$

The first term on the left hand side is the efficiency gain from treasury services, and the second term is the incremental safety-net subsidy from lending (relative to stand-alone gambling). The right hand side stems from the bond issuance cost. Notice that an increase in $\Delta$ relaxes and an increase in $\bar{g}$ tightens (5). We conclude as follows:

Proposition 5 Suppose that $\hat{\theta} \leq \theta(\check{g})$ and $\check{g} \leq \bar{g}$. Then, the equilibrium exhibits bank loan financing and trading (provision of treasury services) if and only if (5) holds, i.e., $\Delta$ large, $\bar{g}$ small, and s large. Corporate sector performance is increasing in $\Delta$ and in the tightness of bank activity restrictions (as long as $\check{g} \leq \bar{g}$ ). For $\Delta$ small, $\bar{g}$ large, and s small, the equilibrium exhibits bond financing and gambling. The introduction of trading opportunities is not necessarily beneficial to society, even if it does not crowd out lending.

The analysis yields a number of interesting insights. First, and obviously so, the presence of scope economies between trading and lending (weakly) improves welfare: it makes 
disintermediation less of a possibility, and it improves efficiency in a lending equilibrium. Second, tight activity restrictions can be counterproductive: if bank activity restrictions are too tight $(\bar{g}<\check{g})$, the bank will not be able to provide complementary banking services. Still, as we will discuss in more detail below, tight activity restrictions $\bar{g}<\check{g}$ could be optimal. Third, disintermediation is still a possibility. As above, the reason is that the corporate sector will have to compensate the bank for giving up gambling rents, making bank loan financing potentially too costly. Now, however, it is not only lending that may be crowded out by trading, but trading too: socially useless trading $(g=\bar{g})$ may crowd out socially useful trading $(g=\check{g})$. Fourth, and relatedly, banks being able to engage in trading could be detrimental to welfare (and financial stability), despite the efficiency-enhancing role of treasury services. Formally, effort in a lending and trading equilibrium is inferior to effort in the absence of trading opportunities if the left hand side of $(5)$ is less than the safety-net subsidy in the absence of trading:

$$
(1-e) \mu \Delta+S(\Delta)-[1-1 / \bar{g}]<S(0)
$$

Comparing this expression with (5), we conclude that trading opportunities can be detrimental to welfare even if in equilibrium the bank engages in efficiency-enhancing trading required for the provision of banking services. However, and in sharp contrast to the case of speculative trading, trading can also be beneficial to society.

Low Risk Trading Strategy. Next, consider the case of $\theta(\check{g})<\hat{\theta}$. In this case, the bank's trading revenues are no longer "safe": they will fully or partially accrue to depositors or the deposit insurance agency. Specifically, for $\theta \in[\theta(\check{g}), \hat{\theta})$, the bank's loan portfolio is insufficient to repay depositors, but trading generates revenues $\breve{g} \geq 1$, which, in turn, is sufficient to repay depositors. Thus, regardless of whether the banks fails or does not fail, the deposit insurance agency's losses will be zero for all $\theta \geq \theta(\check{g})$. For $\theta<\theta(\check{g})$, the bank necessarily fails, and, moreover, its revenues will be insufficient to repay depositors. 
Consequently, the safety-net subsidy amounts to

$$
S^{\text {low }}(\Delta)=\int_{0}^{\theta(\check{g})}(1-e \theta \Pi-(1-e) \theta \Delta) d F(\theta)
$$

which is strictly less than $S(\Delta)$ by $\theta(\check{g})<\hat{\theta}$. The safety-net subsidy from lending only is $S(0)=\int_{0}^{\hat{\theta}}(1-e \theta \Pi) d F(\theta)$. Thus, the gain from providing treasury services relative to lending only is

$$
(1-e) \mu \Delta+S^{\text {low }}(\Delta)-S(0)
$$

This is strictly increasing in $\Delta$ but negative for $\Delta$ small. This differs from the high risk trading strategy case, where the gain from providing treasury services relative to lending only is always positive. The reason that providing treasury services may be unprofitable when the corresponding trading profile has low risk is that depositor preference can give rise to a debt overhang problem. Part or all of the direct returns from trading will accrue to depositors, making trading and treasury service provision a negative NPV project for the bank when $\Delta$ is small.

The corporate finance literature suggests a variety of solutions to the debt overhang problem, such as subordinating the claims of pre-existing creditors to those of new creditors or incorporating projects as bankruptcy-remote subsidiaries. In banking, we have similar institutions. These ultimately boil down to implicit or explicit violations of depositor preference and putting other creditors ahead of the queue. For instance, counterparties in derivative transactions and repurchase agreements are typically granted exemption from automatic stay ("safe harbors"). Such counterparties can then settle their claims before everybody else does. To see how "repo" funding can resolve the debt overhang problem, suppose that the bank engages in a trade whereby it raises $\$ 1$ against pledging securities as collateral, with settlement date just before date 1. At maturity, repo counterparties simply take their collateral, so that trading returns no longer accrue to depositors.

In a similar vein, the bank could issue a covered bond with claim $\check{g}$ due at date 1 and 
secured by the pool of trading securities. Bond investors would have a senior claim on the collateral cash flows, but, due to depositor preference, a junior claim on the remaining assets (loans). At date 1 , the collateral generates $\check{g}$ if $\tilde{\theta} \geq \theta(\check{g})$ and zero otherwise. In the former case, bond investors are paid $\check{g}$ out of the collateral. The effect of this is that, in states $\tilde{\theta} \in[\theta(\check{g}), \hat{\theta})$, trading revenues no longer accrue to depositors or the deposit insurance agency. In the latter case, the collateral generates no return. Moreover, since $\theta(\check{g})<\hat{\theta}$, loan portfolio revenue is insufficient to pay back depositors, and covered bond investors are paid zero. Thus, the present value of the covered bond cash flows is $\$ 1$, just the amount needed to set up the trading business.

Yet another possibility would be to ring-fence the trading business and incorporate it as a bankruptcy-remote subsidiary. Here, however, the rationale for ring-fencing is not to insulate depositors and taxpayers from proprietary trading losses. This would require ring-fencing lending. Rather, the rationale for ring-fencing trading is to protect the returns from low-risk trading strategies required for the provision of key banking services and, in doing so, make sure that such activities are profitable.

Proposition 6 Suppose that $\hat{\theta}>\theta(\bar{g})$. Then, depositor preference may impede the bank's incentive to engage in value-enhancing trading required for the provision of complementary banking services. Explicit or implicit deviations from depositor preference (e.g., ringfencing trading, covered bonds) can facilitate the efficient provision of banking services.

\subsection{Policy Options}

As in the previous section, we conclude with a discussion of policy options.

Bank Activity Restrictions. As risky trading is required for the provision of complementary banking services, it is no longer necessarily optimal to prohibit proprietary trading, even if doing so is feasible and not subject to other costs. The optimal activity restriction is 
either $\bar{g}=1$ or $\bar{g}=\check{g}>1$, and the tradeoff is between deterring gambling on the one hand and facilitating the provision of useful banking services on the other hand. Assuming that the aforementioned debt overhang problem gets resolved, the latter activity restriction is optimal from an efficiency perspective if and only if the left hand side of (5), evaluated at $\bar{g}=\check{g}$, is not smaller than the safety-net subsidy in the absence of trading opportunities,

$$
(1-e) \mu \Delta+S(\Delta)-[1-1 / \check{g}] \geq S(0)
$$

-i.e., $\Delta$ large and $\check{g}$ small. If this inequality holds, effort in the absence of trading will be inferior to effort with trading and provision of banking services. Of course, an even better policy measure, if feasible, would be to tie the permissibility of trading to client-driven activities - i.e., in our context, the provision of banking services. If doing so were feasible, gambling would be deterred, and, at the same time, the provision of value-enhancing banking services would be facilitated. If it were not feasible, the regulator would face a tradeoff and prohibiting trading might or might not be optimal.

As mentioned, the upper bound $\bar{g}$ can also be interpreted as a proxy for financial deepening. This has an interesting implication: the relationship between economic welfare and financial deepening should be non-monotonic. As long as $\bar{g}<\check{g}$, banks cannot engage in the provision of complementary banking services, as financial markets are not sufficiently developed and feasible trading profiles have too little risk. Within this range, economic welfare is decreasing in $\bar{g}$. At $\bar{g}=\check{g}$, it becomes feasible to provide banking services, and welfare jumps upwards. Further increases in financial deepening are again detrimental to welfare. Thus, assuming that the provision of banking services is sufficiently valuable, economic welfare is maximized at some interior level of financial deepening, beyond which further financial deepening would be welfare-destroying.

Fair Deposit Insurance Pricing. With fair deposit insurance pricing, assuming that premia can be made contingent on the bank's risk choices, out-of-equilibrium gambling 
would be deterred and the provision of banking services would be facilitated. Effort would be characterized by

$$
\mu \Pi-\frac{1-(1-e) \mu \Delta}{e}=\psi^{\prime}(e)
$$

As above, fair deposit insurance pricing is optimal if the incremental safety-net subsidy from lending and trading relative to stand-alone gambling is negative:

$$
S(\Delta)-[1-1 / \bar{g}] \leq 0
$$

This will hold if both $\Delta$ and $\bar{g}$ are relatively large-i.e., banking services are highly valuable and financial markets are sufficiently deep. Intuitively, the benefit of fair deposit insurance pricing is that it deters out-of-equilibrium gambling, thus eliminating the need to compensate banks for lost gambling profits and making corporate loans less costly. This benefit becomes more pronounced as financial markets become deeper and banks can take riskier bets. The cost, from an efficiency perspective, stems from the fact that fair deposit insurance pricing also eliminates safety-net subsidies in equilibrium, thus making corporate loans more costly. Thus, fair deposit insurance pricing is optimal when $\Delta$ is large, as in this case the safety-net subsidy that fair deposit insurance pricing would eliminate is small.

Ring-Fencing. Above, we alluded to the possibility of ring-fencing trading as a means to resolve a debt overhang problem arising from depositor preference. Doing so is socially efficient and privately optimal. As in the previous section, however, ring-fencing (the lending business) can also be used as a regulatory tool to limit deposit insurance and the associated subsidies to banks' lending businesses. If doing so were feasible, out-ofequilibrium gambling would be deterred. The lending business would be financed with retail deposits and the trading business with wholesale securities. The bank would engage in trading to facilitate provision of banking services, resulting in additional returns in project failure states and making corporate loans less risky. Effort would be characterized 
by

$$
\mu \Pi-\frac{1-S(\Delta)-(1-e) \mu \Delta}{e}=\psi^{\prime}(e)
$$

Comparing this with the reduced form incentive constraint in the absence of trading opportunities, $\mu \Pi-(1-S(0)) / e=\psi^{\prime}(e)$, we conclude that effort with trading and ring-fencing would exceed effort in the absence of trading opportunities for any $\Delta>0$. Safety-net subsidies would be efficiently deployed in the real economy and welfare would be maximized. This illustrates that ring-fencing can be beneficial. The next section will demonstrate that there can be costs, too.

\section{Discussion}

This section extends the analysis along several dimensions. The following two sections allow for over- and underinvestment, respectively. Section 5.3 considers a version of the model where resource constraints stem from scarcity of talent rather than from scarcity of insured deposits. Section 5.4 provides a discussion of the relative desirability of underpriced guarantees and direct subsidies, and Section 5.5 introduces bank capital requirements.

\subsection{Overinvestment: Gambling by Lending}

Thus far, we have assumed that real investment is socially efficient. This may not necessarily be the case in our economy. Indeed, because of the presence of safety-net subsidies, it could well be the case that investment is efficient for banks and entrepreneurs even if project NPV is negative. An immediate implication is that safety-net subsidies can be detrimental to welfare simply because they may spur overinvestment.

There is another implication. Suppose that our entrepreneurs happen to be commercial real estate developers and that commercial real estate investments happen to have negative NPV. Thus, in the absence of safety-net subsidies, no investment in commercial real estate 
would take place, but with safety-net subsidies, it may well be optimal for the private sector to pursue investment. Consider, now, what happens if we introduce opportunities to trade in arbitrage-free securities markets - i.e., place zero NPV bets. Clearly, assuming that activity restrictions are sufficiently lax, the bank will no longer engage in negative NPV commercial real estate lending once it has the opportunity to engage in financial market betting. The reason is that financial market betting is more efficient: placing bets in financial markets has zero NPV, whereas commercial real estate lending has negative NPV. The introduction of zero NPV investment opportunities prevents the bank from engaging in more-harmful gambling in its lending business.

Proposition 7 If real investment projects have negative NPV, then opportunities to engage in financial market gambling can have positive implications for welfare by preventing more-harmful gambling in the lending business. Furthermore, ring-fencing lending and limiting safety-net subsidies to the lending business can spur gambling by lending and, as such, be detrimental to welfare.

Gambling by lending is likely to be more harmful than financial market betting as the supply of gambling-by-lending opportunities is constrained by the supply of real investment projects. Whereas in securities markets there is a zero NPV bet for any negative NPV bet with the same risk profile (thus banks would never pick negative NPV bets), this may not be so in credit markets. In this circumstance, ring-fencing lending can be counterproductive, as it may spur destructive gambling in the lending business unless deposit insurance is fairly priced or banks face stringent capital requirements.

One can take the analysis a step further by asking what would happen if banks had access to both negative and positive NPV lending opportunities. Suppose that our representative bank has access to a unit mass of positive NPV entrepreneurial projects and a unit mass of negative NPV commercial real estate bets. In this case, ring-fencing lending 
may no longer be counterproductive. While entrepreneurs will have to compensate the bank for lost gambling rents when it devotes insured deposits to entrepreneurial projects rather than to commercial real estate loans, competition in the commercial real estate lending market may well ensure that such gambling rents are small. If so, the threat to engage in gambling by lending would not allow the bank to extract substantially higher loan rates from entrepreneurs, and, consequently, it would be relatively harmless. In any case, it would be less harmful than the threat to gamble in securities markets, where prices are pinned down by absence of arbitrage. Thus, gambling-by-trading rents fully accrue to the bank, making gambling by trading more lucrative than gambling by lending.

\subsection{Credit Rationing}

The flip side of overinvestment is underinvestment or credit rationing. Credit rationing can arise endogenously in models such as ours due to borrower moral hazard. As external funding requirements have negative implications for incentives, it could well be that there is no interest rate that would allow lenders to break even on their investments. This implies that some positive NPV projects would not be undertaken in the presence of financial frictions, representing a loss to society. Safety-net subsidies can mitigate credit rationing, as they constitute an additional source of value for the private sector (e.g., Arping et al. 2010). The overall conclusion of this and the previous section is that safety-net subsidies can have both costs and benefits that we have abstracted from in our main analysis: overinvestment on the one hand and mitigating credit rationing on the other.

\subsection{Scarce Talent}

Much of our preceding analysis relies on the presence of safety-net subsidies. As mentioned, deposit insurance underpricing seems to be the rule rather than the exception (e.g., 
Demirgüc-Kunt et al. 2005). Implicit guarantees, which may be even more important in magnitude than explicit guarantees, tend to be underpriced, too (e.g., Noss and Sowerbutts 2012). In other words, safety-net subsidies from implicit or explicit debt guarantees are a fact, and our framework takes this as given.

Having said this, it is still worth pointing out that the insights proposed in this paper are general enough to not rely on the existence of safety-net subsidies. To see how a model without safety-net subsidies might look like, suppose that banks can make money from selling overpriced securities (or dodgy products) to unsophisticated counterparties. Finding such counterparties requires expertise and skills. Yet talent is scarce, so banks need to make a choice between useful activities (lending and provision of complementary banking services) and useless activities (identifying unsophisticated counterparties and selling dodgy products). Much of the analysis above continues to apply. Financial deepening and innovation may introduce new opportunities for exploiting unsophisticated counterparties. Lending and provision of banking services would require reallocating talent from the "proprietary trading desk" to the lending division and giving up the corresponding rents. As above, trading opportunities make corporate loans more costly and, in the extreme, crowd out bank lending. And socially useless trading might crowd out the socially useful trading required for the provision of complementary banking services.

One can take the argument a step further. Suppose that "useless activities" - selling overpriced securities - are not really useless. Consider market making. Market making is socially useful, as it provides "immediacy" to counterparties, facilitating diversification and risk sharing. This reduces liquidity risk premia and, hence, firms' costs of capital, which, in turn, has positive implications for the real economy. Yet, in market making, securities are typically sold at prices above fair value and bought at prices below fair value (bid-ask spreads are positive). Suppose that talent is scarce so that banks cannot engage in both market making and lending. Suppose, too, that market making allows banks to 
make strictly positive profits, whereas lending markets are perfectly competitive. In this case, opportunities to engage in market making could be detrimental to welfare, despite the usefulness of market making. Society might be better off if banks did not have the opportunity to engage in market making. This is because, as above, banks will have to be compensated for giving up rents when allocating scarce resources to lending, making loans more costly. In this context, a potential policy response would be to curb banks' engagement in market making. A better policy measure would be to address the source of the inefficiency at hand: namely, scarcity of talent. ${ }^{34}$

\subsection{Debt Guarantees versus Direct Subsidies}

As discussed, underpriced debt guarantees seem to be a pervasive feature in banking. While our framework takes this as given, and a complete analysis of the cost and benefits of subsidizing banks via underpriced debt guarantees is beyond the scope of this paper, it is worth providing a brief discussion.

As seen above, subsidizing banks is not necessarily detrimental to welfare. To the extent that competitive pressure forces banks to fully or partially pass on subsidies to borrowers, subsidization entails lower loan rates. This can have positive implications for credit availability and real economic activity. However, subsidies can also give rise to inefficiencies. Conceptually, subsidized debt guarantees involve state-contingent transfers of wealth to banks and their investors in the event of bank failure. Thus, even abstracting from deadweight costs due to taxation, guarantees can be harmful merely because they reward failure and, in doing so, distort incentives (e.g., Keeley 1990). In the context of our model, this distortion may not materialize in the lending business (see the discussion

\footnotetext{
${ }^{34}$ Likewise, in our base model, scarcity of cheap funds could be relieved through underpriced central bank funding. In essence, banks would be endowed with cheap money to play with in an attempt to reduce the opportunity cost of allocating cheap funds to lending. However, this policy could be very costly (e.g., on political grounds), as it might involve large transfers of wealth from the wider public to banks.
} 
following Proposition 1, but also see the discussion in Section 5.1), but it does arise in the trading business. If so, and if subsidies are beneficial, why, then, give subsidies through debt guarantees, and not directly in the form of non-contingent cash infusions?

There are three potential answers. First, even if direct subsidies were more efficient than underpriced debt guarantees, it could be that they are less costly on political grounds. As debt guarantees lead to payouts only in the distant future and only in worst-case scenarios, voters may find them easier to swallow than direct subsidies. Second, governments may simply be unable to commit to not bail out depositors and other bank debt holders in case of bank failure. At the same time, political constraints may prevent governments from charging banks for the corresponding costs upfront. Third, direct subsidies may invite abuse. One reason for this might be that failure is required in order to benefit from a guarantee, while it is not required in order to benefit from a direct subsidy. Direct subsidies may, therefore, spur excessive entry by parties who are actually not endowed with real projects or investment opportunities and who would just take the money and run (cf., Arping et al. 2010). In other words, abuse and diversion of subsidies may be more of a problem with direct subsidies than with debt guarantees. Such abuse can be costly to the extent that it makes it more difficult to provide support where it is really needed.

\subsection{Capital Requirements}

We have abstracted from capital requirements in our main analysis, but we now provide a brief discussion. To fix ideas, suppose that for each dollar of risk-weighted assets, banks need to hold $C \in[0,1]$ dollars of equity capital. Thus, if our bank invests $\$ 1$ in loans or securities, it will have to raise $C$ dollars of equity capital. Let us assume w.l.o.g. that the bank continues to raise $\$ 1$ of insured deposits, so that the funds raised through issuing equity are held as cash (we abstract from sovereign debt). In the absence of trading opportunities, the bank fails if and only if $e \theta \Pi+C<1$ or $\theta<(1-C) /(e \Pi)=\hat{\theta}$. The 
wealth of existing bank shareholders becomes

$$
U_{B}(e, R)=\int_{0}^{R / \Pi} e \theta \Pi d F(\theta)+\int_{R / \Pi}^{1} e R d F(\theta)-1+\int_{0}^{(1-C) /(e \Pi)}(1-C-e \theta \Pi) d F(\theta)
$$

where the last term is the safety-net subsidy, which is strictly decreasing in $C$. Thus, the key effect of capital requirements is that they reduce the safety-net subsidy (obviously, therefore, the bank would not issue equity if not required to do so). Going through the same steps as above, it is, then, straightforward to show that equilibrium effort in the absence of trading will be characterized by

$$
\mu \Pi-\frac{1-S(C)}{e}=\psi^{\prime}(e)
$$

where $S(C)$ denotes the safety-net subsidy as a function of capital $C$. As effort is increasing in the safety-net subsidy, which, in turn, is decreasing in $C$, higher capital requirements will have a negative effect on effort. The intuition is straightforward: as non-subsidized equity is a more expensive funding source than subsidized deposits, ${ }^{35}$ capital requirements will lead to higher loan rates, thus stifling effort. Indeed, a 100-percent capital requirement is, in terms of efficiency, equivalent to fair deposit insurance pricing in our setup. Thus, the effect of capital requirements on the bank's failure rate is ambiguous because, on the one hand, capital raises the bank's loss absorption capacity, but, on the other hand, the bank experiences more defaults in its loan portfolio.

Let us now introduce gambling opportunities. It is straightforward to show that effort in a lending equilibrium is characterized by

$$
\mu \Pi-\frac{1-S(C)+(1-C)(1-1 / \bar{g})}{e}=\psi^{\prime}(e)
$$

where $(1-C)(1-1 / \bar{g})$ is the safety-net subsidy under stand-alone gambling. The incremental safety-net subsidy from lending is

$$
\xi(C)=S(C)-(1-C)(1-1 / \bar{g})
$$

\footnotetext{
${ }^{35}$ On this and related matters, see Admati et al. (2010).
} 
As above, real sector efficiency (effort) is increasing in the incremental safety-net subsidy. Note that $\xi(1)=0$ and $\xi(0)>0$ if and only if $\bar{g}<\hat{g}$ (see Section 3). Furthermore, $\xi(C)$ is strictly convex. The implication is that effort is maximized either at $C=0$ (no capital requirement) or $C=1$ (full capital requirement). More specifically:

Proposition 8 If activity restrictions $\bar{g}<\hat{g}$ are feasible, then a policy regime with subsidized deposit insurance in conjunction with an activity restriction $\bar{g}$ but no capital requirements outperforms a regime with fair deposit insurance pricing or capital requirements. Otherwise, the optimal policy regime involves a full capital requirement or, equivalently, fair deposit insurance pricing. This policy regime implements an equilibrium with bank loan financing, no gambling, and entrepreneurial effort $e^{\text {fair }}$.

In other words, in our setup, fair deposit insurance pricing and capital requirements are, in terms of their efficiency implications, equivalent policy tools. Overall, the analysis suggests that while capital requirements can be costly in economies where banks have little opportunity to engage in trading - as in these economies there would be a tradeoff between real sector efficiency and banking system stability — no such tradeoff arises when banks can engage in lucrative gambling. This is because in economies where high-risk speculative trading is feasible, stringent capital requirements would enhance both financial stability and real sector efficiency precisely by making such trading less lucrative.

\section{Empirical Implications}

Our analysis yields a number of empirical predictions. The first set of empirical implications has to do with the relationship between financial market development and economic outcome variables such as economic growth (real economic activity), corporate loan rates, corporate default rates, and measures of financial stability. As discussed earlier, to the extent that banks can engage in riskier trading as financial markets become more developed, 
the model would, at least for some parameter constellations, predict a non-monotonic relationship between financial market development and these variables. This is because, on the one hand, financial market deepening enables banks to engage in riskier and, hence, more lucrative gambling, which is detrimental to real economic activity and financial stability. On the other hand, however, financial market deepening also facilitates the provision of financial services that complement lending, enhance real sector efficiency, and reduce corporate default rates.

Implication 1 The relationship between financial market development and economic outcome variables, such as real sector economic growth, might be non-monotonic, attaining a maximum at some level, after which further development would be counterproductive.

This prediction appears to be consistent with Cecchetti and Kharroubi (2012), who, based on a sample of developed and emerging economies, show that financial development is good for economic growth only up to a point, after which it becomes a drag on growth. Restricting the sample to more advanced economies, they also show that a fast-growing financial sector is detrimental to aggregate productivity growth. ${ }^{36}$

The qualifier "might" in the above implication applies because matters are complicated by the fact that financial market development should also reduce bond issuance transaction costs, making disintermediation more of a possibility but also less costly for firms. By implication, the model would predict a positive relationship between measures of corporate efficiency and financial market development at very high levels of development. The

\footnotetext{
${ }^{36}$ Beck, Degryse, and Kneer (2012), in another cross-country setting, regress measures of economic growth and growth volatility on measures of financial intermediation activity and, separately, on total financial sector size, encompassing both intermediation and non-intermediation activities. They find that, while intermediation activities increase growth and reduce volatility, an expansion of the financial sector along other dimensions stimulates growth only over short time horizons and comes at the expense of higher volatility. In the long-run, a larger financial sector appears to have no effect on real sector outcomes.
} 
corresponding economy would be characterized by a high degree of disintermediation, at least as far as the funding of large corporations is concerned. Such companies would tap the bond market. Smaller firms may resort to bank loan financing from institutions that simply do not have the means or expertise to exploit the trading opportunities provided by financial markets (e.g., small community banks). Larger banks, in turn, may shift more and more resources from traditional lending to riskier market-based trading activities as markets become deeper, a trend that may abate once banks face more stringent capital requirements. This prediction seems to be broadly consistent with the evolution of banking and financial markets over the past two or so decades.

A second caveat concerns the impact of financial market development on bank failure rates and financial stability. The preceding analysis shows that they can be-but don't necessarily have to be - a tradeoff between banks' engagement in trading and stability. Trading can be completely benign, supporting the provision of risk-reducing and efficiency-enhancing banking services. However, even if banking services reduce corporate loan delinquency rates, it could still be that the risk of the corresponding trading profiles is such that it ultimately makes banks riskier.

Implication 2 There can be-but does not necessarily have to be-a tradeoff between effciency and financial stability. In particular, for low-risk trading profiles, one might expect a positive relationship between trading and banking system stability, whereas for high-risk trading profiles, the opposite might prevail, even if banking services facilitated through trading reduce loan portfolio risk.

The impact of non-interest, fee-based banking activities (such as trading) on bank risk and return has been examined in a number of papers. Stiroh (2004) finds that greater reliance on non-interest income - trading revenue, in particular - is associated with lower risk-adjusted bank returns and higher bank risk. ${ }^{37}$ Using a large international sample of

\footnotetext{
${ }^{37}$ See, also, Stiroh (2006) and Stiroh and Rumble (2006).
} 
banks, Demirgüc-Kunt and Huizinga (2010) detect a U-shaped relationship between noninterest income and bank risk (inverse of Z-score), which appears to be consistent with our model. ${ }^{38}$ Brunnermeier, Dong, and Palia (2012) document that banks with higher non-interest income have a higher contribution to systemic risk than traditional banking (deposit taking and lending).

At a conceptual level, our analysis suggests that there is an important difference between observed trading volumes and trading opportunities. This has the following implication:

Implication 3 Empirical designs where economic outcome variables are regressed on measures of trading activity or risk may not necessarily lead to appropriate policy conclusions.

Of course, there are many reasons why OLS regressions may lead to wrong conclusions, but our analysis highlights one particular channel. Taken at face value, the base model without value-enhancing trading predicts that when feasible trading profiles have low risk, banks abstain from trading. Yet, the threat of trading is still a drag on the economy, as it enables banks to extract excessive rents from the productive sector. If we allow for value-enhancing trading, banks may engage in trading, but such trading would be benign. Thus, one might detect a negative relationship between, say, corporate loan delinquency rates and trading activity, even though default rates might be lower if banks did not have the opportunity to engage in trading. ${ }^{39}$ This suggests that there is a difference between observed trading activities and trading opportunities. The opportunity to engage in trading

\footnotetext{
${ }^{38}$ Demirgüc-Kunt and Huizinga (2010) also detect a U-shaped relationship between non-deposit funding shares and bank risk. This can be consistent with our analysis in that in our model, banks will use wholesale funding if and only if they engage in value-enhancing trading. An increase in wholesale funding at low levels may, then, be indicative of relatively low-volume and low-risk trading, which, through its effect on corporate default rates, would decrease bank risk, whereas higher levels of wholesale funding may indicative of relatively high-volume and high-risk trading, with the opposite effect on bank risk.

${ }^{39} \mathrm{And}$, of course, one might detect a positive sign between, say, corporate default rates and, say, trading volumes, even when trading causes lower default rates, simply because trading is endogenous.
} 
can have a negative impact on bank failure risk and real economic activity, even if, in the data, one observes a favorable relationship between actual trading activity and economic outcome variables (or no relationship whatsoever). This underpins the desirability of empirical designs that exploit natural experiments or instrument trading with (potentially exogenous) measures of bank activity restrictions. ${ }^{40}$

\section{Conclusion}

The thrust of our argument is simple. If providing socially useful services (lending) forces banks to give up rents from socially less useful - or even useless - activities (gambling), then the mere opportunity to engage in such activities can be detrimental to welfare. This is because banks, when devoting scarce resources to lending, must be compensated for giving up gambling rents. Corporate loan rates rise, stifling real economic activity. Speculative trading may even crowd out lending, forcing firms to seek costly bond financing. And, regardless of whether banks ultimately engage in gambling, the mere possibility of doing so will make banks riskier, jeopardizing banking system stability.

By contrast, when proprietary trading is required for the provision of value-enhancing complementary banking services, banks may actually engage in too little trading-for two reasons: First, socially useless trading aimed at extracting subsidies may crowd out the socially useful trading required for the provision of banking services. Second, depositor preference can give rise to a debt overhang problem, making it unprofitable for banks to

\footnotetext{
${ }^{40}$ Along these lines, see Kneer (2012) for an empirical study of whether the financial sector may absorb too much talent, in which she exploits variation in U.S. branching deregulation. Brunnermeier et al. (2012) exploit the bankruptcy of Lehman Brothers to examine whether banks with different non-traditional income contribute differently to systemic risk measures when they face the unexpected shock of the Lehman bankruptcy. DemirgücKunt and Huizinga (2010) use information on bank types (e.g., whether a bank is a commercial bank) to instrument for trading in their IV regressions.
} 
provide banking services when the corresponding trading profiles have little risk.

We have discussed several policy options. Fair deposit insurance pricing, while suboptimal in the absence of trading opportunities, can be optimal in the presence of trading opportunities. This is because it reduces safety-net subsidies to banks, thereby making it less lucrative for banks to place bets in financial markets and, hence, reducing the opportunity cost of allocating resources to lending. This supports the real economy and can also foster banks' engagement in socially useful trading activities. Bank capital requirements have a similar effect. Regulators might also want to restrict banks' ability to engage in trading, but doing so runs the risk of putting too-tight restrictions in place. This can undermine banks' ability to engage in socially useful trading or reduce their incentive to do so. Trading may then migrate to the unregulated shadow banking system, with potentially adverse systemic consequences (cf., Duffie 2012a). And, to the extent that trading is required for the provision of banking services that complement lending, banks may be less able or inclined to provide such services to corporate borrowers. However, our analysis also shows that limiting banks' ability to engage in socially useless trading can help to "crowd in" socially useful trading. The key issue here is whether it is practically feasible to distinguish between "socially useful" and "socially useless" trading.

Recent policy proposals suggest the possibility of ring-fencing banks' traditional lending and deposit taking business (Vickers et al. 2011; Liikanen et al. 2012). While such a solution would reduce the possibility of cross-pledging cash flows and the corresponding risk diversification benefits, it would allow regulators to limit the safety net and the implied subsidies to the lending and deposit taking business. This would have the advantage of making speculative trading in securities markets less lucrative for banks. In our model, this can have positive implications not only for financial stability, but also for real economic activity. Yet our analysis also shows that ring-fencing lending can backfire. Precisely by making gambling in securities markets less lucrative, ring-fencing lending may spur even 
more destructive gambling in lending markets. This emphasizes the importance of stringent bank capital requirements. While the policy proposals involve ring-fencing lending and deposit taking, our analysis also points to the potential desirability of ring-fencing tradingthat is, insulating investors funding the trading business from losses made elsewhere. When trading profiles required for the provision of banking services have low risk, banks may have too little of an incentive to invest in such socially useful trading, unless its returns are protected from the claims of depositors or deposit insurance agencies.

In our analysis of value-enhancing trading, we have restricted attention to activities that directly complement bank lending. Of course, there can be other channels through which trading by banks can create value for society. For instance, market making in corporate bonds can be beneficial to society by making secondary markets more liquid, thus facilitating diversification and risk sharing. The key question here is what are the benefits of combining "traditional" lending and deposit taking with bond market making. One can imagine that banks, in their role of lenders, internalize a larger fraction of the benefits of bond market making than specialized non-bank market makers. For instance, reductions in firms' costs of capital due to enhanced bond liquidity may ultimately improve firms' ability to repay their loans. Due to this "side benefit", banks may be willing to provide market making services at lower cost than non-bank market makers. However, one can also imagine that combining lending with bond market making can give rise to conflicts of interest or diseconomies. This is an interesting avenue for future research.

Trading on own account is required for a whole array of useful banking services, including market marking, risk management, and corporate treasury services. It is unfortunate that poor governance and moral hazard at banks have created a momentum of distrust that might lead to severe restrictions on banks' ability to provide such services. 


\section{References}

Admati, A., DeMarzo, P., Hellwig, M., and P. Pfleiderer, 2010, Fallacies, irrelevant facts, and myths in the discussion of capital regulation: Why bank equity is not expensive, Working paper, Stanford GSB.

Allen, F., and E. Carletti, 2006, Credit risk transfer and contagion, Journal of Monetary Economics 53, 89-111.

Arping, S., 2013, Credit protection and lending relationships, Journal of Financial Stability, forthcoming.

Arping, S., Loranth, G., and A. Morrison, 2010, Public initiatives to support entrepreneurs: Credit guarantees versus co-funding, Journal of Financial Stability 6, 26-35.

Beck., T., Degryse, H., and C. Kneer, 2012, Is more finance better? Disentangling intermediation and size effects in financial systems, Working paper, Tilburg University.

Bolton, P., and M. Oehmke, 2011. Credit default swaps and the empty creditor problem, Review of Financial Studies 24, 2617-2655.

Bolton, P., Santos, T., and J. Scheinkman, 2011, Cream skimming in financial markets, Working paper, Columbia University.

Boot, A., and L. Ratnovski, 2012, Banking and trading, Working paper, University of Amsterdam.

Brunnermeier, M., Dong, G., and D. Padlia, 2012, Banks' non-interest income and systemic risk, Working paper, Princeton University.

Cahuc, P., and E. Challe 2012, Produce of speculate? Asset bubbles, occupational choice, and efficiency, International Economic Review 53, 1105-1131.

Campello, M., and R. Matta, 2012. Credit default swaps, firm financing and the economy, Working paper, Cornell University.

Cecchetti., S., and E. Kharroubi, Reassessing the impact of finance on growth, Working paper, Bank for International Settlements. 
Chow, J., and J. Surti, 2011, Making banks safer: Can Volcker and Vickers do it?, Working paper, International Monetary Fund.

Clifford Chance, 2011, Depositor preference in the G20, Manuscript.

Demirgüc-Kunt, A., Karacaovali, B., and L. Laeven, 2005, Deposit insurance around the world: A comprehensive database, Working paper, World Bank.

Demirgüc-Kunt, A., and H. Huizinga, 2010, Bank activity and funding strategies: The impact on risk and returns, Journal of Financial Economics 98, 626-650.

Drucker., S., and M. Puri, 2007, Banks in capital markets, In: Eckbo, E. (Ed.), Handbook of Corporate Finance, chapter 5, North-Holland.

Duffie, D., 2012a, Market making under the proposed Volcker Rule, Working paper, Stanford University.

Duffie, D., 2012b, Drawing boundaries around and through the banking system, In: World Economic Forum (Ed.), The Financial Development Report 2012, 39-46.

Glode, V., Green, R., and R. Lowery, 2012, Financial expertise as an arms race, Journal of Finance $67,1723-1759$.

Keeley, M., 1990, Deposit insurance, risk, and market power in banking, American Economic Review 80, 1183-1200.

Kneer, C., 2012, The absorption of talent into finance: Evidence from U.S. banking deregulation, Working paper, Tilburg University and Dutch Central Bank.

Liikanen, E., et al., 2012, Final report, High-Level Expert Group on Reforming the Structure of the EU Banking Sector.

Loranth, G., and A. Morrison, 2012, Tying in universal banks, Review of Finance 16, 481-516.

Murphy, K., Shleifer, A., and R. Vishny, 1991, The allocation of talent: Implications for growth, Quarterly Journal of Economics 90, 630-49. 
Noss, J., and R. Sowerbutts, 2012, The implicit subsidy of banks, Working paper, Bank of England.

Parlour, C., and G. Plantin, 2008. Loan sales and relationship banking. Journal of Finance 63, $1291-1314$.

Parlour, C., and A. Winton, 2013, Laying off credit risk: Loan sales versus credit default swaps, Journal of Financial Economics 107, 25-45.

Philippon, T., 2008, The evolution of the US financial industry from 1860 to 2007: Theory and evidence, Working paper, NYU Stern School of Business.

Philippon, T., and A. Reshef, 2012, Wages and human capital in the US financial industry: 19092006, Quarterly Journal of Economics 127, 1551-1609.

Stiroh, K., 2004, Diversification in banking: Is noninterest income the answer?, Journal of Money, Credit and Banking 36, 853-882.

Stiroh, K., 2006, A portfolio view of banking with interest and noninterest activities, Journal of Money, Credit, and Banking 38, 2131-2161.

Stiroh, K., and A. Rumble, 2006, The dark side of diversification: The case of U.S. financial holding companies, Journal of Banking and Finance 30, 2131-61.

Thakor, A., 2012, The economic consequences of the Volcker Rule, Manuscript, Center for Capital Markets Competitiveness.

Vickers, J., et al., 2011, Final report, Independent Commission on Banking.

Wagner, W., 2007, The liquidity of bank assets and banking stability. Journal of Banking and Finance 31, 121-139

Wuergler, T., 2009, Of bubbles and bankers: The impact of financial booms on labor markets, Working paper, University of Zurich. 


\section{Appendix: Proofs}

\section{Proof of Proposition 1 and Related Corollaries}

The reduced form optimization problem is

$$
\begin{array}{ll}
\max _{e} & U_{E}(e, R(e))=e \mu \Pi-\psi(e)-1+\int_{0}^{\hat{\theta}}(1-e \theta \Pi) d F(\theta) \\
\text { s.t. } & \\
& \mu \Pi-\frac{1-\int_{0}^{\hat{\theta}}(1-e \theta \Pi) d F(\theta)}{e}=\psi^{\prime}(e)
\end{array}
$$

where $\hat{\theta}=1 / e \Pi$. Notice that (IC') can be rewritten as

$$
\varphi(e)=e \mu \Pi-1+\int_{0}^{1 / e \Pi}(1-e \theta \Pi) d F(\theta)-e \psi^{\prime}(e)=0
$$

By assumption, $U_{E}(e, R(e))$ is strictly concave over the relevant range and, hence, $\varphi(e)$ is strictly concave over the relevant range too, since $\varphi^{\prime \prime}(e)=U_{E}^{\prime \prime}(e, R(e))-e \psi^{\prime \prime \prime}(e)-\psi^{\prime \prime}(e)<0$, by $\psi^{\prime \prime}(e)>0$ and $\psi^{\prime \prime \prime}(e) \geq 0$. Furthermore, $\varphi(1)<0$. Thus, $\varphi(e)=0$ has at most two solutions, both of which are interior. Since, by assumption, an equilibrium with an investment exists, $\varphi(e)=0$ must have a solution. Furthermore, since any such solution is inferior to the unconstrained optimum by (IC') and $1-\int_{0}^{\hat{\theta}} d F(\theta)>0$ (since $e>1 / \Pi$ at the optimum), the optimal solution must be given by the largest solution, denoted by $e^{*}$. Notice that at this largest solution it generically must be the case that

$$
\varphi^{\prime}\left(e^{*}\right)=\mu \Pi-\int_{0}^{1 / e^{*} \Pi} \theta \Pi d F(\theta)-e^{*} \psi^{\prime \prime}\left(e^{*}\right)-\psi^{\prime}\left(e^{*}\right)<0
$$

otherwise $e^{*}$ would not be the largest solution of $\varphi(e)=0$.

Consider, next, the case of fair deposit insurance pricing. The optimization problem is

$$
\begin{array}{cc}
\max _{e} & U_{E}(e, R(e))=e \mu \Pi-\psi(e)-1 \\
\text { s.t. } & \\
& \varphi(e)=e \mu \Pi-1-e \psi^{\prime}(e)=0
\end{array}
$$

As above, the optimum is given by the largest solution of the reduced form incentive constraint $\varphi(e)=0$. Let $e^{\text {fair }}$ denote this solution. Notice that $e^{*}>e^{\text {fair }}$ by $\int_{0}^{1 / e \Pi}(1-e \theta \Pi) d F(\theta)>0$ and concavity.

Lastly, consider the case of bond financing. Under bond financing, equilibrium effort is given by the largest solution of

$$
\varphi(e)=e \mu \Pi-(1+s)-e \psi^{\prime}(e)=0
$$


denoted by $e^{\text {bond }}$, and, again, it generically must be the case that $\varphi^{\prime}\left(e^{\text {bond }}\right)<0$. Notice that $e^{\text {fair }}=e^{\text {bond }}$ if and only if $s=0, e^{\text {bond }}<e^{*}$, and, by implicit differentiation, $d e^{\text {bond }} / d s=$ $1 / \varphi^{\prime}\left(e^{\text {bond }}\right)<0$.

\section{Proof of Lemma 1}

Consider a candidate equilibrium with bank loan financing-i.e., $R<R^{\text {bond }}$. Notice that the loan rate pins down effort $e$. If the bank engages in lending only, it funds loans with deposits and its payoff is

$$
E_{\theta} \min [e \theta \Pi, e R]-1+S
$$

where

$$
S=\int_{0}^{\hat{\theta}}(1-e \theta \Pi) d F(\theta)
$$

is the safety-net subsidy. If the bank engages in lending and gambling, it has to raise $\$ 1$ of wholesale funding. As wholesale investors just break even in equilibrium and gambling has zero NPV, the bank's payoff is

$$
E_{\theta} \min [e \theta \Pi, e R]-1+S^{\mathrm{gbl}}
$$

where $S^{\text {gbl }}$ is the safety-net subsidy with lending and gambling. We now show $S \geq S^{\text {gbl }}$ for all $g$. We have either $\theta(g) \geq \hat{\theta}$ or $\theta(g)<\hat{\theta}$. In the former case, for $\tilde{\theta}<\hat{\theta}$, the trading business generates a gross return of zero and lending generates revenues $e \tilde{\theta} \Pi<1$. Thus, the bank fails, and the deposit insurance agency's loss is $1-e \tilde{\theta} \Pi$. For $\tilde{\theta} \geq \hat{\theta}$, the bank's lending revenues are sufficient to pay back depositors and, hence, the deposit insurance agency's loss is zero. Hence, in the former case, $\theta(g) \geq \hat{\theta}$, we have $S^{\mathrm{gbl}}=S$. In the latter case, trading generates a return $g \geq 1$ for $\tilde{\theta} \geq \theta(g)$. Thus, for $\tilde{\theta} \geq \theta(g)$, the bank's revenues are sufficient to pay back depositors and, hence, the deposit insurance agency's loss is zero. For $\tilde{\theta}<\theta(g)$, trading generates no income and, moreover, the bank's lending revenues are insufficient to pay back depositors. Thus, the deposit insurance agency's loss is $1-e \tilde{\theta} \Pi$. Consequently, in the latter case, $\theta(g)<\hat{\theta}$, the safety-net subsidy is

$$
S^{\mathrm{gbl}}=\int_{0}^{\theta(g)}(1-e \theta \Pi) d F(\theta)<S
$$

by $\theta(g)<\hat{\theta}$. Thus, the safety-net subsidy with lending and gambling is weakly inferior to the safety-net subsidy with lending only, and, hence, the bank will not gamble if it lends. 


\section{Proof of Proposition 2}

Consider a candidate equilibrium with bank loan financing. The reduced form optimization problem is

$$
\begin{array}{ll}
\max _{e} & U_{E}(e, R(e))=e \mu \Pi-\psi(e)-1+\int_{0}^{\hat{\theta}}(1-e \theta \Pi) d F(\theta)-[1-1 / \bar{g}] \\
\text { s.t. } & \\
& \varphi(e)=e \mu \Pi-1+\int_{0}^{\hat{\theta}}(1-e \theta \Pi) d F(\theta)-[1-1 / \bar{g}]-e \psi^{\prime}(e)=0
\end{array}
$$

where $\hat{\theta}=1 / e \Pi$. As above, the optimum, denoted by $e^{* *}$, is given by the largest solution of (ICG), and, generically, we must have $\varphi^{\prime}\left(e^{* *}\right)<0$. Thus,

$$
d e^{* *} / d \bar{g}=-\frac{\varphi_{\bar{g}}\left(e^{* *}\right)}{\varphi^{\prime}\left(e^{* *}\right)}=-\frac{-1 / \bar{g}^{2}}{\varphi^{\prime}\left(e^{* *}\right)}<0
$$

Thus, effort is strictly decreasing in $\bar{g}$.

We now analyze the choice between bank loan and bond financing. Entrepreneurs prefer bank loan over bond financing if and only if $R<R^{\text {bond }}$, which by (IC) reduces to $e^{* *}>e^{\text {bond }}$, which, as shown in the text, reduces to (3). Let

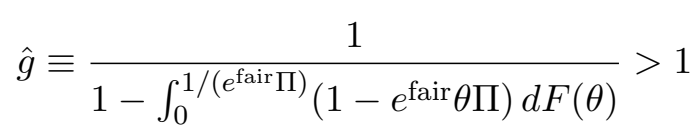

and notice that $e^{* *}=e^{\text {fair }}$ at $\bar{g}=\hat{g}, e^{* *}>e^{\text {fair }}$ for $\bar{g}<\hat{g}$ (as $e^{* *}$ is strictly decreasing in $\bar{g}$ ), and $e^{* *}<e^{\text {fair }}$ for $\bar{g}>\hat{g}$. Thus, for $\bar{g}<\hat{g}$, entrepreneurs prefer bank loan financing for any $s \geq 0$ since $e^{\text {bond }} \leq e^{\text {fair }}<e^{* *}$. Conversely, for $\bar{g} \geq \hat{g}$, since $e^{\text {bond }}$ is strictly decreasing in $s$, there is some threshold $\hat{s}>0$ such that $e^{* *}>e^{\text {bond }}$ if and only if $s>\hat{s}$.

\section{Proof of Propositions 3 to 8}

See earlier proofs and the discussion in the text. 